\title{
Effect of Intravenous Treatment with the Oxytocin Antagonist Atosiban on Circulating Progesterone in the Ewe
}

Todd M. Ramboldt

West Virginia University

Follow this and additional works at: https://researchrepository.wvu.edu/etd

\section{Recommended Citation}

Ramboldt, Todd M., "Effect of Intravenous Treatment with the Oxytocin Antagonist Atosiban on Circulating Progesterone in the Ewe" (2011). Graduate Theses, Dissertations, and Problem Reports. 3323. https://researchrepository.wvu.edu/etd/3323

This Thesis is protected by copyright and/or related rights. It has been brought to you by the The Research Repository @ WVU with permission from the rights-holder(s). You are free to use this Thesis in any way that is permitted by the copyright and related rights legislation that applies to your use. For other uses you must obtain permission from the rights-holder(s) directly, unless additional rights are indicated by a Creative Commons license in the record and/ or on the work itself. This Thesis has been accepted for inclusion in WVU Graduate Theses, Dissertations, and Problem Reports collection by an authorized administrator of The Research Repository @ WVU. For more information, please contact researchrepository@mail.wvu.edu. 
Effect of Intravenous Treatment with the Oxytocin Antagonist Atosiban on Circulating Progesterone in the Ewe

Todd M. Ramboldt

Thesis submitted to the

Davis College of Agriculture, Natural Resources and Design $\square$

DWJ HWO IJ IQDD8 QYHHWW

in partial fulfillment of the requirements

for the degree of

Master of Science

in

Reproductive Physiology

E. Keith Inskeep, Ph.D., Chair

Robert A. Dailey, Ph.D.

Jorge A. Flores, Ph.D.

Faculty of Reproductive Physiology

Morgantown, West Virginia

2011

Keywords: Corpus Luteum, Oxytocin, Atosiban, Progesterone, Sheep 


\begin{abstract}
Effect of Intravenous Treatment with the Oxytocin Antagonist Atosiban on Circulating Progesterone in the Ewe
\end{abstract}

Todd M. Ramboldt

Effects of oxytocin on the ovine corpus luteum have been controversial for a number of years. The present study investigated the effects of atosiban, a combined oxytocin and vasopressin $1 \mathrm{~A}$ antagonist, administered systemically to ewes on post estrus day 8 to 10 . Atosiban was given in four bolus intravenous injections at $0,60,120$ and 180 minutes with blood sampling every 15 minutes from -60 through 480 minutes. Concentrations of serum progesterone $\mathrm{ng} / \mathrm{ml}$ were measured via radioimmunoassay. A $\log _{10}$ transformation of progesterone values was conducted to account for the heterogeneity of variance of the values. During the treatment interval (0 to 240 minutes), $\log _{10}$ concentrations of progesterone were lower in ewes treated with $20 \mathrm{mg}(0.99)$ than in the 5 or $10 \mathrm{mg}$ treated groups $(1.00 ; \mathrm{P}<0.05)$. Control ewes $(\mathrm{P}<0.0001)$ differed from ewes treated with atosiban $(5,10$ or $20 \mathrm{mg})$. During times greater than 240 minutes (hours 4 to 24$), \log _{10}$ concentrations of progesterone decreased in control ewes (1.04) and were lower in the ewes treated with 5,10 or $20 \mathrm{mg}(1.01)$ of atosiban $(\mathrm{P}<0.005)$. There was also a significant difference $(\mathrm{P}<0.05)$ when comparing the $20 \mathrm{mg}$ group $(1.01)$ to the ewes treated with 5 and $10 \mathrm{mg}$ of atosiban (1.02). Over the entire sampling period, mean $\log _{10}$ progesterone concentrations were lower $(\mathrm{P}<0.001)$ in ewes treated with atosiban (1.00) compared to the control group (1.05). Among doses of atosiban, $\log _{10}$ concentrations of progesterone were lower $(\mathrm{P}<0.0001)$ in ewes treated with $20 \mathrm{mg}$ (0.99) atosiban than in ewes treated with $5 \mathrm{mg}$ or $10 \mathrm{mg}$ (1.01) atosiban. The overall effect of systemic treatment with atosiban in this study was to decrease mean $\log _{10}$ concentrations of progesterone relative to control ewes, which is in agreement with earlier findings using intraluteal infusion. The most effective dose of atosiban was 20 $\mathrm{mg}$. In conclusion, systemic treatment with atosiban decreased concentrations of progesterone during the treatment phase of the experiment. Atosiban delivered in $20 \mathrm{mg}$ maintained the lowest values in contrast to the control ewes and ewes treated with 5 or 10 $\mathrm{mg}$ of atosiban throughout the duration of the experiment. 


\section{Table of Contents:}

Table of Contents

List of Figures

Acknowledgements $\quad$ V

Introduction 1

Lutenization 3

$\begin{array}{ll}\text { Corpora lutea } & 6\end{array}$

$\begin{array}{ll}\text { Regulation of progesterone } & 15\end{array}$

$\begin{array}{ll}\text { Luteolysis } & 17\end{array}$

$\begin{array}{ll}\text { Oxytocin } & 19\end{array}$

Actions of oxytocin within the corpus luteum 29

$\begin{array}{ll}\text { Vasopressin 1A } & 30\end{array}$

Atosiban and Barusiban $\quad 32$

Statement of the Problem 34

$\begin{array}{ll}\text { Materials and Methods } & 35\end{array}$

$\begin{array}{ll}\text { Statistics } & 37\end{array}$

$\begin{array}{ll}\text { Results } & 37\end{array}$

$\begin{array}{ll}\text { Discussion } & 42\end{array}$

$\begin{array}{ll}\text { Conclusion } & 45\end{array}$

$\begin{array}{ll}\text { Literature Cited } & 47\end{array}$ 


\section{List of Figures:}

Figure 1. Mean corpus luteum weight ( \pm SEM). Bars represent treatment group means (n $=6$ ) for control, 5, 10 or $20 \mathrm{mg}$ of atosiban. There were significant differences the between 5 and $10 \mathrm{mg}$ dosages $(\mathrm{P}<0.03)$.

Figure 2. Mean $\log _{10}$ concentrations of progesterone $( \pm$ SEM). Bars represent treatment group means $(\mathrm{n}=6)$ for control, 5,10 or $20 \mathrm{mg}$ of atosiban. There was a significant difference between ewes treated $(5,10$ or $20 \mathrm{mg})$ with atosiban to control ewes $(\mathrm{P}<$ $0.0001)$ also when comparing the $20 \mathrm{mg}$ dose to the 5 and $10 \mathrm{mg}$ doses $(\mathrm{P}<0.05)$.

Figure 3. Mean $\log _{10}$ concentrations of progesterone $( \pm$ SEM). Bars represent treatment group means $(\mathrm{n}=6)$ for control, 5,10 or $20 \mathrm{mg}$ of atosiban. There were significant differences for control versus treatment $(0 \mathrm{mg}$ vs 5,10 and $20 \mathrm{mg})(\mathrm{P}<0.005)$, and between the high dose versus the lower dosages $(20 \mathrm{mg}$ vs 5 and $10 \mathrm{mg})(\mathrm{P}<0.05)$.

Figure 4. Mean $\log _{10}$ concentrations of progesterone $( \pm$ SEM). Bars represent treatment group means $(\mathrm{n}=6)$ for control, 5,10 or $20 \mathrm{mg}$ of atosiban. There were significant differences for control versus treatment $(0 \mathrm{mg}$ vs 5,10 and $20 \mathrm{mg})(\mathrm{P}<0.0001)$. 


\section{Acknowledgements}

It would be very difficult to name each and every person who has assisted in this two-year journey. I first would like to thank my mother, Terri Ramboldt, for providing words of encouragement and support throughout life. If it weren't for you, I would not be in the position I am right now. To my Dad, Mike Ramboldt, you left this world too early however, during our time together you instilled many values in me that I will hold onto for a lifetime.

To the members of the faculty and my committee members, you are second to none. There wasn't a faculty member at the Davis College that I couldn't ask a question or for assistance. Dr. Inskeep, without your scientific knowledge, this experiment and my master's degree would not be possible. I am very thankful for your constant support and critical proof-reading skills. Dr. Dailey, thank you, not only for making every day interesting, pushing me to think outside of the box and teaching me that there is always more than one-way to look at a question or a statement. Your assistance in the assay lab and running the statistics is highly appreciated. Dr. Flores, thank you for your assistance in the collection of the corpora lutea and processing of the samples. A couple other faculty members that I feel have went above and beyond that call of duty through my masters are: Dr's. Lewis, Felton, Minch, and Hileman. You all have always been there to give me advice or give me a good laugh, thank you.

To my fellow graduate students and peers, thank you. Thank you, not only for assistance on my project and allowing me to assist on your projects. Tina Dow, Jennie Zambito, Kevin Shaffer, Nate Dean, and Casey Nestor, you all had integral parts in this 
process and it could not have been completed without your help. A special thanks goes out to Dr. Goodman's OVX team, you all gave up your free time to help, Dr. Hileman, Gail and Casey, thank you. 


\section{Introduction}

In most spontaneous ovulators, the period of sexual receptivity in females is referred to as standing heat or estrus (Heape, 1900). Twenty-four to 30 hours after estrus a surge of luteinizing hormone (LH) (Bindon et al., 1979; Quirke et al., 1979) causes ovulation of the preovulatory follicle and onset of luteinization (Warbritton, 1934; McClellan et al., 1975; Parry et al., 1980; Murphy, 2000). Luteinization is the morphological and biochemical remodeling process that forms a transient organ known as the corpus luteum (CL) (Murphy, 2004).

Fabricius (1604) and Adelmann (1672) first described the CL as "numerous little glands" on the porcine ovary. Research on the CL has focused on three main stages: growth (luteinization), maintenance, and regression (luteolysis) (Murphy, 2000). The most important hormone in reproduction and the hormone secreted from the CL in the largest amount during the maintenance phase is progesterone (Murphy, 2000; Sangha et al., 2002). Large luteal cells in the CL are responsible for secretion of the majority of progesterone of the ewe (Fitz et al., 1982).

Oxytocin was first discovered by Sir Henry Dale (1906) when he found that human posterior pituitary glandular tissue contracted the uterus of a pregnant cat. Dale named this neuropeptide "oxytocin" meaning swift birth (Viero et al., 2010). Oxytocin is produced not only in the hypothalamus and delivered via the posterior pituitary gland (du Vigneaud 1956; Viero et al., 2010), but also in large luteal cells of the CL (Wathes and Swann, 1982). Receptors for oxytocin have been localized in the uterus (Soloff et al., 1979); endometrium, myometrium (Roberts et al., 1985; Sheldrick \& Flint, 1985; Ayad \& 
Wathes 1989), oviduct (Ayad et al., 1990) and cervix (Ayad et al., 1991). Receptors have been found recently on small luteal cells of the CL in the ewe (Niswender et al., 2007). Hence, researchers have studied effects of oxytocin on estrous cycle length, secretion of progesterone by the CL and luteolysis.

Armstrong and Hansel (1959) reported that treatment, depending on the stage of the cycle with oxytocin had an effect on estrous cycle length in the cow. Daily injections initiated before day seven shortened the diestrous phase of the cycle. However, if daily injections began after day 15 , the estrous cycle and continued unabated beyond estrus, the subsequent cycle was shortened. Milvae and Hansel (1980) found that giving subcutaneous injections of oxytocin on days four through six reduced jugular concentrations of progesterone on day eight.

In an attempt to investigate further the effects of oxytocin on the CL, Mankey (2009) examined the effects of a combined oxytocin and vasopressin 1A receptor antagonist, atosiban, on the response of the ovine CL to exogenous prostaglandin $F_{2} \alpha$. Atosiban was delivered directly into the CL via a mini-osmotic pump. None of the four doses $(0.25,1.25 .2 .50$ or $5 \mu \mathrm{g} / \mathrm{h})$ of atosiban altered the response of serum progesterone to an injection of $\mathrm{PGF}_{2} \alpha$ or affected the weight of CL treated with $\mathrm{PGF}_{2} \alpha$ or vehicle when compared to reference ewes. However, concentrations of progesterone before treatment with $\mathrm{PGF}_{2} \alpha$ appeared to be reduced. In a subsequent experiment, concentrations of progesterone were decreased during the 48-hour sampling period when $5 \mu \mathrm{g} / \mathrm{h}$ of atosiban was delivered continuously by the mini-pump. Hence, the first objective of this study was to determine if a series of four bolus intravenous injections of atosiban would affect serum progesterone in the mid-luteal phase ewe. The second 
objective was to determine if there was a dosage effect on serum progesterone when 0,5 , 10 , or $20 \mathrm{mg}$ of atosiban were injected intravenously. If atosiban were effective by the systemic route, a further objective was to examine changes in other hormones ( $\mathrm{LH}$ and $\mathrm{PGF}_{2} \alpha$ ) and genetic changes in the CL.

\section{Review of Literature}

\section{$\underline{\text { Luteinization }}$}

Luteinization can be described as a morphological and biochemical remodeling process that ensues after rupture of the preovulatory follicle and forms a transient ovarian organ known as the corpus luteum (CL) (Murphy, 2004). In this highly specialized process, two steroidogenic luteal cells are formed in response to the ovulatory stimulus (Warbritton, 1934; Murphy, 2000) from two endocrine cells in the follicle: granulosal and thecal cells. The granulosal cells are derived from mesothelial cells originating from the ovarian surface epithelium during embryonic formation of the ovarian follicles and become the large luteal cells (Juengel et al., 2002), which are generally spherical when viewed histologically. Corner (1937) established that granulosal cells were an integral part of the CL. The thecal cells, steroidogenic cells of the theca interna, become the small luteal cells, which are smaller in diameter $(15.8 \mu \mathrm{m})$ compared to large to $(29.2 \mu \mathrm{m})$ luteal cells in the ewe (Rodgers et al., 1984) and are distinguishable by a stellate appearance.

Although outnumbered by the theca-derived, small luteal cells, the large luteal cells make up 25 to $35 \%$ of the volume of the CL (Nett et al., 1976; Rodgers et al., 1984). The large luteal cells are typical secretory cells with features such as Golgi 
complexes, rough endoplasmic reticulum and secretory granules, and the small luteal cells have an in-folded nucleus (Schwall et al., 1986). This description applies for sheep (Warbritton, 1934), cattle (Meidan et al., 1990), and the ferret (Mead and Joseph, 1988). i

The theca of the follicle can be separated into two parts: theca interna and theca externa. The theca interna contains the glandular thecal cells, connective tissue, and small blood vessels; whereas, the theca externa is connective tissue and smooth muscle-like cells that form the outer layer of the ovulating follicle (Warbritton, 1934). At ovulation, the follicle collapses, and a rapid influx of blood vessels, originating in the thecal layer, invade the antrum (Murphy, 2001). The granulosal cells of the developing follicle had functioned as a fused cell through intercellular gap junctions (Van Niekerk et al., 1975). Intercellular bridges are broken down during ovulation and reformed during luteinization. Reynolds and others (1999) suggested that there is intercellular communication in the luteal parenchyma based upon the expression of gap junctions during luteinization. In domestic ruminants, remodeling of the granulosal cells is very important in the formation and function of the CL. There is evidence that some of the small theca-derived luteal cells differentiate into large luteal cells (Cran, 1983; Alila and Hansel, 1984; Farin et al., 1986).

The processes of ovulation and subsequent luteinization occur in response to a surge of luteinizing hormone (LH) released from the anterior pituitary by gonadotropinreleasing hormone $(\mathrm{GnRH})$, which is released from the surge center of the hypothalamus. The surge causes a number of morphological and biochemical changes in the ovulatory follicle, such as an eight-fold increase in the volume of the granulosal cells by hypertrophy, proliferation and migration of the thecal cells, and a shift in steroid 
synthesis from estradiol 17- $\beta$ to progesterone (Warbritton, 1934; Donaldson and Hansel, 1965; McClellan et al., 1975; Parry et al., 1980; Murphy, 2000). Functional lutenization of both granulosal and thecal cells increased basal cAMP, secretion of progesterone, and involved morphological changes in the mitochondria in association with the increased intra cellular P-450scc (Richards et al., 1986; Rodgers et al., 1986).

The two-cell, two-gonadotropin hypothesis proposed by Armstrong and Dorrington (1977) has been greatly supported in the rationale of follicular steroid conversion and production. In this proposal, the early steps of follicular steroidogenesis take place solely in the thecal layer with the conversion of cholesterol to progesterone and subsequently into androgens, more specifically androstenedione and testosterone. Androgens diffuse into the avascular granulosa where, under the influence of folliclestimulating hormone (FSH), they are converted by cytochrome $\mathrm{p} 450$ aromatase (Richards, 1980) to estrogens. The granulosal cells are remodeled by the differentiationdependent modification of the steroid pathway.

Steroid acute regulatory protein (StAR), the rate-limiting factor in steroid synthesis, transfers cholesterol from the cytoplasm to the inner mitochondrial membrane, where is it converted to pregnenolone via P450scc and $3 \beta$-hydroxysteroid dehydrogenase (Stocco, 2001). Both StAR and 3B-hydroxysteroid dehydrogenase are highly upregulated during luteinization and their presence decreases or practically disappears after CL regression (Chedrese et al., 1990; Albrecht et al., 2001).

The combined shift in cells and proteins produces a shift of ovarian hormones. Estrogens are the primary product from the growing and dominant follicles. During and 
after ovulation there is a shift in the product to progesterone. Secretion of progesterone by the newly formed CL will be low during the first few days and elevated during the mid-luteal stage of the CL (Lipsett, 1978), because of increased uptake of cholesterol, the parent material for progesterone. The 3-hydroxy-3-methylglutaryl coenzyme A reductase (HMG-CoA) limits an early step in the synthesis of cholesterol (La Voie et al., 1997). Although present at all stages of the luteal cycle, HMG-CoA does not seem to be a major factor in the synthesis of progesterone from cholesterol (Plotkin et al., 2002). Two other sources of cholesterol are high-density lipoproteins (HDL), which are vital to rodents, and the low-density lipoproteins (LDL), which are more important in most other species (Murphy and Silavin, 1989). The receptors for lipoproteins are increased seven-fold during formation of the CL and contribute to the increase in progesterone production by the mid-luteal phase CL (La Voie et al., 1997, Rajapaksha et al., 1997; Li et al., 1998). During luteinization, cholesterol is transferred to the Golgi apparatus by a bulk cholesterol transfer protein know as Niemann-Pick, Type C1 protein (NPC-1) (Gevry et al., 2002). Two other mediators in the delivery of cholesterol to the CL are metastatic lymph node 64 protein (MLN-64) and StAR like-protein, which are located in the endosomes (Zhang et al., 2002).

\section{$\underline{\text { Corpora Lutea }}$}

Short (1977) reviewed the historical basis for depiction of the CL. De Graff was distinguished most for his description of the Graafian follicle, but he also provided the initial description of the CL. He described "globular bodies" that appeared on the ovary of rabbits after coitus and remained until after parturition and which gave an indication for the number of fetuses present (De Graff, 1672). Warbritton (1934) published data 
describing the cells that complete the $\mathrm{CL}$ in the ewe, but like other researchers during that time, she did not know all of the exact functions of the gland.

The different stages of luteal maturity and differentiation bring about three different colors that can be observed by the naked eye on the ovaries of an exercised reproductive tract: red, yellow and white. Red is indicative of the corpus hemorrhagicum or "bloody body" that is formed immediately after ovulation. Yellow is associated with the functional CL; the gland was officially termed that, meaning yellow body. White refers to the corpus albicans or "white body" seen after the regression of the corpus luteum. The colors are attributed to Malpighi's description of bovine ovaries in 1697 (Adelmann, 1966).

Up until 1886, many scientists believed that the CL was just a scar that developed after ovulation. However, Knauer (1886) established through ablation-replacement studies that the ovary was a gland of internal secretion. Beard (1897) and Prenant (1898) hypothesized that the CL had specific functions in gestation, lactation, uterine development, and secreted substances into the blood stream. This early hypothesis was supported by Fraenkel (1903) and Magnus (1901), who isolated luteal hormones seven years after the experiments conducted by Beard and Prenant. The major advances in the field of reproductive physiology and more specifically luteal research came after the development of radioimmunoassays (RIA) to detect hormones in blood serum or plasma (Niswender and Midgley, 1970). The RIA was far more sensitive than the standard bioassays that were used previously to measure hormones. 
Three different lifespans of CL have been identified: long, short, and ultra short (Stouffer, 2006). The CL classified as long-lived would be those seen in canines; these animals are monoestrous species that have a prolonged cycle that can last from 2 weeks to 6 months (Rothchild, 1981; Concannon, 1986; Olson et al., 1989). In these species, the functional life span does not differ if the CL originated in a fertile or non-fertile cycle. Species with CL in this classification include dogs, wolves, foxes, skunks and cats (Eckstein and Zuckerman, 1956; Asdell, 1964) along with roe deer, armadillo and marsupials (Tyndale-Biscoe, 1973; Sharman, 1976; Hoffmann et al., 1978).

The ultra short-lived CL are characteristic of rodents (Hilliard, 1973; Freeman, 2006), in which a truly functional CL does not form unless mating occurs. Rodents do not have a true luteal phase and have estrous cycle lengths around 4 or 5 days. Females become pseudopregnant and keep the CL functional for 10 to 13 days when true pregnancy did not occur in response to mating (Gibori et al., 1988; Bowen-Shaver and Gibori, 2004).

The focus of this review will concentrate on the short-lived CL, which occurs in polyestrous species, animals with frequent ovarian cycles such as primates and human beings. The lifespan of the CL is finite, around two weeks in those species, but is prolonged if pregnancy ensues. In primates, if fertile insemination occurs, this extended period allows for movement of the embryo into the uterus where it beings to implant (Stouffer and Hearn, 1998). A similar sequence of events occurs in ungulates, which include the domesticated farm animals such as cattle, sheep and goats. In this case, the CL forms rapidly after ovulation and will continue to function until days 15 to 21 postestrus (Hansel et al., 1973; Goodman and Inskeep, 2006). If fertile insemination does 
not occur, the functional CL will undergo luteolysis, and the estrous cycle will be repeated again. In the ungulates, follicular growth occurs during the luteal phase of the estrous cycle (Fortune, 1994). This early growth allows for rapid follicular growth after luteolysis, leading to another ovulation within two to three days. In contrast, the primate has less opportunity for antral follicle growth during the luteal phase, and subsequent ovulation and luteinization require about two weeks for the next ovulatory follicle to emerge (di Zerega and Hodgen, 1981; Zeleznik, 2001).

After completion of luteinization, two types of steroidogenic cells play vital roles in the secretory function of the CL. In addition to the large and small steroidogenic cells, there are other cell types that play an important role in the CL, including endothelial cells, smooth muscle cells, macrophages, leucocytes and pericytes (Alila and Hansel, 1984). The CL secretes multiple hormones. Progesterone is the most recognized steroid hormone, along with small amounts of estradiol $17 \beta$ in the case of sheep (Sangha et al., 2002). The CL produces prostaglandin $\mathrm{F}_{2} \alpha$, a hormone that plays a large part in luteolysis, and peptide hormones, including oxytocin, vasopressin, inhibin and relaxin (Fields, 1991).

Small and large luteal cells can be differentiated by immunocytochemistry and histochemistry (Fritz and Fitz, 1991; Sharma and Sharma, 1998). Large luteal cells represent approximately $40 \%$ of the volume of the CL in the goat, 33 to $38 \%$ in the sheep and $40 \%$ in the cow. Large luteal cells are around $10 \%$ of the total cell numbers in the CL in the goat, 8 to $14 \%$ in the sheep and 3.5\% in the cow (Meyer, 1991). The large luteal cells in the ewe are characterized by a nucleus that contains a nucleolus and euchromatic nucleoplasm (Hoyer et al., 1988). With regard to small luteal cells, 18 to $23 \%$ of the 
volume of the CL in the sheep is made up of these cells, around $20 \%$ in the goat and $28 \%$ in the cow. Of the total cell numbers, 23 to $36 \%$ are small luteal cells in the sheep, approximately $25 \%$ in the goat and $26 \%$ in the cow (Farin et al., 1986; Fields and Fields, 1996; Sharma and Sharma, 1998). These small luteal cells contain smooth endoplasmic reticulum and mitochondria; however, they lack rough endoplasmic reticulum and secretory granules (Rodgers and O'Shea, 1982). The large luteal cells in the mature CL of the sheep have a 1.8-fold greater frequency of mitochondria per unit volume of cytoplasm compared to the small luteal cells; this indicates a higher metabolic investment in differentiation and development (Kenny et al., 1989). In addition, the large luteal cells are spherical ( 22 to $50 \mu \mathrm{m}$ ), and the small luteal cells are polyhedral, 12 to $22 \mu \mathrm{m}$ in diameter (Rodgers and O'Shea, 1982; Singh and Prakash, 1988; Sharma and Sharma, 1998). In sheep, the newly-formed CL weighs as much as 600 to $700 \mathrm{mg}$ in just a few days (Farin et al., 1986; Jablonka-Shariff et al., 1993). Steroidogenic activity can be related to the increase in the luteal cell diameter and will increase from days 6 to 8 and remain fairly constant until day 15, when regression (luteolysis) will begin (Cunningham et al., 1975; Juengle et al., 1993).

In the cow, luteal cell types have been termed type I and type II (Greenstein et al., 1958) relative to their expected functionality. Experiments have been conducted to characterize further the two steroidogenic cell types in the ovine CL. The most outstanding difference in cell type is the diameter, which has been acknowledged in numerous species, including the cow and the sheep. Small and large cells were identified in the ewe (Priedkalns et al., 1968) and cow (Ursely and Leymarie, 1979; Koos and Hansel, 1981). 
In an early study, Fitz and others (1982) looked at the differences in the two cell types in the ewe. Ewes that were superovulated with human chorionic gonadotropin (hCG) were used in this experiment, and 5 to 17 corpora lutea per ewe were removed by midventral laparotomy. The tissue was sliced into $0.5 \mathrm{~mm}$ sections and was separated on a Beckman JE-6 elutriator rotor, equipped with a Sanderson chamber, into 4 separate fractions. Small luteal cells were contained mostly in fractions 2 and 3, and fraction 4 was limited to predominately large luteal cells. The cells were analyzed for the rate of secretion of progesterone, number of specific binding sites and responsiveness to LH/hCG, $\mathrm{N}^{6}, \mathrm{O}^{2}$-dibutyryladenosine 3'-5' -cyclic monophosphoric acid (dbcAMP), and prostaglandins $\mathrm{E}_{2}$ and $\mathrm{F}_{2} \alpha\left(\mathrm{PGE}_{2}\right.$ and $\left.\mathrm{PGF}_{2} \alpha\right)$. The secretion of progesterone was 20 -fold greater in the large luteal cells than in the small luteal cells without stimulation. However, the responses to LH and dbcAMP in the small luteal cells were greater when compared to the large luteal cells. Large luteal cells had 3,074 receptors for $\mathrm{LH} / \mathrm{hCG}$ and the small luteal cells had 33,260 receptors; whereas, the receptor sites for prostaglandins $E_{2}$ and $\mathrm{F}_{2} \alpha$ were localized mostly in the large luteal cells $\left(68,143 \mathrm{~F}_{2} \alpha\right.$ and $\left.10,995 \mathrm{E}_{2}\right)$. In contrast, the small luteal cells contained only 2,115 receptors for prostaglandin $F_{2} \alpha$ and 904 for prostaglandin $\mathrm{E}_{2}$. The results demonstrated a clear-cut distinction between the large and small luteal cells in the ovine CL. Progesterone appeared to be secreted generally by the large luteal cells and seemed to be independent of LH. The small luteal cells secreted small amounts of progesterone; however, they responded dramatically to LH or dbcAMP (Fitz et al., 1982).

Progesterone secretion during late luteal phase of the estrous cycle is independent of LH, although LH receptors are present on both large and small cells of the ovine CL 
(Rodgers et al., 1984). McNeilly, Crow and Fraser (1992) looked at the effect of a gonadotropin-releasing hormone $(\mathrm{GnRH})$ antagonist on episodic progesterone secretion or CL function in ewes. Scottish Blackface ewes were treated intra-muscularly with a GnRH antagonist at a rate of $1 \mathrm{mg}$ per $\mathrm{kg}$ of body weight on day 4 or 11 of the luteal phase. Blood samples were collected at 10- or 15- minute intervals between 0 and 8, 24 and 32, and 48 to 56 hours after the GnRH antagonist and daily from estrus for the duration of the 22-day treatment. Treatment with the antagonist beginning on day 4 of the luteal phase had no effect on luteal function until days 11 and 13, when progesterone was lower than the controls. Concentrations of FSH were unchanged by antagonist treatment on day 4 or day 11; however, no pulses of LH occurred in the treated ewes during the administration of the antagonist, and LH was suppressed for 3 days post treatment. The findings demonstrated that progesterone is released in an episodic manner from the CL and is independent of the secretion of LH until day 11. Suppression of LH for 3 days did not play a role in progesterone secretion or induce premature luteolysis (McNeilly et al., 1992).

Mechanisms that control the ovine CL were investigated in 1973 by a group of researchers in England and France with regard to DNA/RNA content, tissue weight and concentration of progesterone in ovarian venous blood (Denamur et al., 1973). Ewes were between 12 to 14 months of age and were hysterectomized on days 9 to 12 of the estrous cycle. Twenty-seven animals were euthanized 27, 60, 128 and 135 days after hysterectomy. The fresh weight of the luteal tissue, content of DNA, RNA and the concentration of progesterone in ovarian vein blood were determined. In the other ewes, hypophysectomies were carried out 20 to 50 days after hysterectomy. Two different 
techniques were used to remove pituitary function; the first technique was a complete removal of the gland, and the other technique was to section the pituitary stalk and remove the adjacent pars tuberalis tissue. In hysterectomized ewes that received cortisol, $(\mathrm{n}=37), \mathrm{CL}$ were removed and studied at $24,48,72$, or 96 hours or 12 days after hypophysectomy. Ewes in a second group $(\mathrm{n}=84)$ were hysterectomized and were given cortisol daily following hypophysectomy; ewes in this group received FSH, LH, LH + FSH, prolactin + FSH, prolactin + LH or prolactin + FSH + LH by intramuscular injections or continuous intravenous infusion for 12 days.

Following hysterectomy alone, weight of the CL remained constant until day 60 and decreased by days 128 and 135 along with DNA and RNA. The progesterone content in the CL demonstrated that CL function was still maintained after hysterectomy through day 135. In ewes in which the pituitary was removed completely or the pars tuberalis was destroyed, the results differed among treatments. When the pituitary was removed, weight of the CL began to decline within 24 hours and continued to decrease rapidly for three days, then leveled off between days 3 and 12. Progesterone followed the same pattern in that the amount declined within 24 hours and by 72 hours was 5 to $7 \%$ of the controls. In ewes in which the pituitary stalk was removed and the pars tuberalis was destroyed, concentrations of progesterone, DNA and RNA and CL weight were not different than observed in the hypophysectomized ewes. Injections of prolactin (250 to 1000 i.u/day) maintained the CL for 12 days after hypophysectomy, while 50 i.u/day was unable to maintain the CL. Combination treatments of $.25 / .5 \mathrm{mg}$ of $\mathrm{LH}+$ prolactin were luteotrophic and increased the weight of the CL; however, other combinations did not 
increase CL weight. Therefore, both prolactin and LH were considered necessary for the maintenance of the ovine CL.

However, Kaltenbach and others (1967) challenged the findings of Denamur's group. They found that FSH, prolactin or estrogen did not demonstrate luteotrophic properties in hypophysectomized ewes and only constant infusion of crude LH maintained the CL. In incubated ovine luteal tissue, only the addition of LH increased progesterone concentration. The addition of FSH or prolactin had no effect on progesterone synthesis (Kaltenbach et al., 1967). Both groups concluded that pituitary support is necessary throughout the estrous cycle to maintain a functional CL (Kaltenbach et al., 1968).

The general actions of progesterone secreted by the CL are important to the maintenance of pregnancy. Progesterone acts on the reproductive tract to calm and prepare it for initiation and maintenance of pregnancy. The effects of progesterone are mediated through ligand-inducible transcription factors (Moutsatsou and Sekeris, 1997). Ligands control the expression of genes by binding to response elements on the DNA and previous exposure to estrogen induced the production of receptors for progesterone (Kraus and Katzenellenbogen, 1993; Kaneko et al., 1993; Ing and Tornesi, 1997). Progesterone receptors are required for progesterone to act on the reproductive tract. One action of progesterone is to down regulate the receptors for estradiol, thus blocking the mitogenic actions of estrogen (Brenner et al., 1974; Simpson et al., 1987; Fairchild and Pate, 1989; Kraus and Katzenellenbogen, 1993; Iwai et al., 1995; Ing and Tornesi, 1997). 
During the follicular phase of the cycle, progesterone inhibited mitosis of the endometrium by blocking the estrogenic effect of inducing proliferation (Cummings and Yochim, 1984; Padykula et al., 1989). Progesterone also induced myometrial quiescence by increasing the resting potential and preventing coupling of the myometrial cells, which down regulated the voltage dependent calcium channels (Barta, 1986; Sharma and Buetter, 1993). Myometrial contractions are limited via progesterone blocking the ability of estradiol to induce $\alpha$-adrenegic receptors (Bottari et al., 1983).

\section{$\underline{\text { Regulation of progesterone }}$}

Gap junctions play a role in the regulation of progesterone secretion by ovine luteal cells. Gap junctions are contact-dependent pathways within the CL that are thought to be essential for the maintenance of the normal luteal tissue (Redmer et al., 1991; Del Vecchio et al., 1994; Redmer \& Reynolds 1996 and Grazul-Bilska et al., 1997a, 1997b). Gap junctional intracellular communication is involved in many intracellular processes, including exocrine and endocrine signaling. Gap junctions facilitate transport of nutrients, ions and regulatory molecules between adjacent cells. Gap junctions play a role in regulation and coordination of luteal cells (Grazul-Bilska et al., 1997a , 1997b, Sohl \& Willecke, 2004), and respond to systemic and local regulators of luteal tissue such as cytokines, second messengers, hormones and growth factors (Grazul-Bilska et al., 2001). LH and dbcAMP increase the rate of gap junctional intercellular communication between luteal cells and progesterone secretion (Redmer et al., 1991). The major connexin expressed within luteal cells during the estrous cycle is $\mathrm{Cx} 43$, which is localized in the borders of the luteal cell and forms gap junctional channels for the intercellular communication (Grazul-Bilska et al., 1997a,b). 
Borowczyk and coworkers (2007) collected ovaries from superovulated ewes to obtain multiple CL per ewe. The ovaries were dissected, and corpora lutea were removed for testing in culture. These authors looked first at four concentrations of steroidogenic cells and their response to LH or dbcAMP. The CL was incubated for 24-hours, and the medium was collected and assayed for progesterone. Contact dependent gap junctional intercellular communication was determined by using a fluorescent dye and interactive laser cytometry. Immunohistochemistry was conducted to identify steroidogenic cells. The rates of gap junction intercellular communication and $\mathrm{Cx} 43$ mRNA expression were affected by the day of the estrous cycle, cell density and treatment. Progesterone secretion changed with changes in $\mathrm{Cx} 43$ mRNA expression, and the rates of gap junctional intercellular communication. The $\mathrm{Cx} 43 \mathrm{mRNA}$ was identified on the borders of all the luteal cells. These results demonstrated a positive correlation between progesterone secretion and $\mathrm{Cx} 43 \mathrm{mRNA}$ expression and gap junctional intercellular communication of luteal cells and that gap junctions are involved in steroidogenesis of in ovine CL (Borowczyk et al., 2007).

The effect of progesterone on estrous cycle length is very important. In the follicular phase of the cycle, concentration of progesterone is relatively low, whereas the concentration of estrogen is relatively high. Increasing concentrations of estradiol 17- $\beta$ act via the hypothalamic-pituitary gonadal axis to stimulate low-amplitude, highfrequency pulses of LH, which drive the Graffian follicle to ovulate (Lucy et al., 1992). After development of the CL, progesterone reduces the frequency of LH pulses and blocks the surge of GnRH from the hypothalamus (Attardi et al., 1992; Kawai and Clark, 1986). The ovine CL secretes progesterone throughout the luteal phase until around day 
15 or 16 , when secretion decreases as a result of luteolysis and the cycle will be repeated with a new ovulation.

\section{$\underline{\text { Luteolysis }}$}

Luteolysis is the cyclic regression of the CL and is caused by the episodic secretion of uterine $\mathrm{PGF}_{2} \alpha$. This secretion can act locally on the CL or via systemic circulation (McCracken et al., 1999). Prostaglandin $F_{2} \alpha$ is the major luteolytic hormone in sheep (McCracken et al., 1972) and is released from the uterus with small peaks recorded on day 12 and subsequent declines in progesterone (Scaramuzzi et al., 1974; Baird et al., 1975; Ottobre, 1979).

Sharma and Fitzpatrick (1974) investigated the effect of estradiol-17 $\beta$ on prostaglandin $\mathrm{F}_{2} \alpha$ secretion in the anestrous ewe. Clun Forest ewes were assigned to four groups; each ewe received an intramuscular injection of estradiol-17 $\beta$ followed later by intravenous injections of oxytocin in two doses separated by one hour. The amount of estradiol varied among groups with group 1 receiving $0 \mu \mathrm{g}$, group 2, $50 \mu \mathrm{g}$ and groups 3 and 4, $1 \mathrm{mg}$. Oxytocin was given in paired doses of 0.4 followed by 2 units for groups 2 and 3, or of 2 followed by 10 units for groups 1 and 4 . Oxytocin was administered 24hours after estradiol injection. Posterior vena caval blood samples were collected every 6 hours from 3 days before estradiol injection to 24 hours after and every 5 minutes for 30 minutes and once again at 60 minutes after each oxytocin injection. Estradiol pretreatment increased concentrations of prostaglandin $\mathrm{F}_{2} \alpha$ in response to oxytocin. Oxytocin had no effect on concentrations of prostaglandin $\mathrm{F}_{2} \alpha$ when administered alone; however, in estradiol pre-treated ewes, a marked release of prostaglandin $F_{2} \alpha$ occurred 
within 5 minutes after the oxytocin injection, followed by a decline to low concentrations within 20 to 25 minutes post injection. When a second dose of oxytocin was administered an hour later, no further increase in the production of prostaglandin $F_{2} \alpha$ occurred. The authors suggested that estrogen potentiated oxytocin-induced release of prostaglandin $F_{2} \alpha$ from the uterus and that these injections may completely empty the prostaglandin $F_{2} \alpha$ storage in the uterus, which may not be replenished within one hour (Sharma and Fitzpatrick, 1974).

Cooke and Ahmad (1994) conducted an experiment to determine if prostaglandin $\mathrm{F}_{2} \alpha$ induced the release of oxytocin from ovine $\mathrm{CL}$ in vitro. Luteal tissue was retrieved from euthanized Welsh Mountain ewes on day 6 or 12 after observed estrus, sliced and weighed. The tissue was preincubated for 45 minutes or 6 hours and then incubated for 60 minutes in $\mathrm{PGF}_{2} \alpha$. Six different concentrations of $\mathrm{PGF}_{2} \alpha(0,1,10,100,1000$, or $10000 \mathrm{nM}$ ) were added to incubated tissue. The day-12 CL did not demonstrate a different response to the varying amounts of $\mathrm{PGF}_{2} \alpha$ or the length of the preincubation. In the day-6 CL, oxytocin was secreted in a dose dependent manner as the concentration of $\mathrm{PGF}_{2} \alpha$ increased. If incubation was extended the luteal cells secreted more oxytocin. The increased secretion of oxytocin from the day-6 CL supported the suggested hypothesis that more oxytocin was secreted during mid-cycle in the CL (Cooke and Ahmad, 1994).

The ultrastructure and function of ovine $\mathrm{CL}$ in response to $\mathrm{PGF}_{2} \alpha$ treatment were investigated by Umo (1975). Ten Clun Forest ewes were detected in estrus by a vasectomized ram; the day the ewes were marked was designated as day 1 of the estrous cycle. Saphenous vein catheters were placed in all the ewes on day 9, and blood samples 
were collected twice daily before 6 ewes were treated with $10 \mathrm{mg} \mathrm{PGF} 2 \alpha$ i.m. on day 10 , four times after the treatment at 3-hr intervals and once on the day after removal of the CL. The remaining ewes served as controls and received vehicle alone. Samples were assayed for concentrations of progesterone. The dose of $\mathrm{PGF}_{2} \alpha$ used had been found to be luteolytic (Douglas and Ginther, 1973). Twelve hours after the $\mathrm{PGF}_{2} \alpha$ injection, the ovaries of the ewes were removed and the CL were dissected and fixed. Histological slices were placed on wax. The ovaries of the control ewes were removed on day 15, and both control and treated ovaries were fixed for electron microscopy. Mean concentrations of progesterone fell from $4.8 \pm 0.2 \mathrm{ng} / \mathrm{ml}$ the day before treatment to $1.3 \pm 0.4$ by 6 hours after $\mathrm{PGF}_{2} \alpha$ treatment, and continued to fall to $0.5 \pm 0.4,12$ hours after the injection of $\mathrm{PGF}_{2} \alpha$. In ewes treated with $\mathrm{PGF}_{2} \alpha$, there was an accumulation of lipid droplets and a decrease in the amount of smooth endoplasmic reticulum. A change in shape of the mitochondria and a decrease in the number of membrane-bound granules also were noted in the $\mathrm{PGF}_{2} \alpha$-treated group (Umo, 1975).

\section{Oxytocin}

Oxytocin is a central nervous system neuropeptide containing nine amino acids that was first discovered in 1906 by Sir Henry Dale, who found that human posterior pituitary glandular tissue extract contracted the uterus of a pregnant cat. With this new knowledge, he named the neuropeptide "oxytocin," for swift birth (Viero et al., 2010). Vincent du Vigneaud was the first to sequence a peptide hormone, oxytocin, in 1953, and for his laboratory work was awarded the Nobel Prize in 1955 (du Vigneaud, 1956). This nonapeptide has been viewed as a hypothalamic neuropeptide that is released into 
circulation via the neural lobe of the pituitary and in turn induced uterine contractions during parturition and milk ejection during lactation. Oxytocin is the strongest uterotonic agent known and is commonly used to induce labor. An antagonistic analog to oxytocin, atosiban, is currently used to prevent preterm uterine contractions in women; that effect reflects the role for oxytocin in human labor (UKMi, 2001).

Oxytocin has other roles in the reproductive and social behaviors than just inducing uterine contractions. These roles include mediating social behaviors (Young et al., 1998), maternal behavior, sexual receptivity, and partnership bonding, so that some have concluded that oxytocin could be termed the "love hormone." Oxytocin receptors are expressed in the pituitary, kidney, ovary, testis, heart, thymus, vascular epithelium, osteoclasts, cancer cells, adipocytes, myoblasts and pancreatic islet cells (Gimpl \& Fahrenholz, 2001).

The proposed actions of oxytocin are all mediated through a single oxytocin receptor. The receptor is a seven transmembrane receptor and is a member of the class 1 family of G protein-coupled receptors (Gimpl \& Fahrenholz, 2001). These protein receptors include three vasopressin receptor subtypes, ( V1a, V1b, V2 ) and the oxytocin receptor. That forms a subfamily of structurally closely related receptors. The members of this family, with exception of the $\mathrm{V} 2$ receptor, bond with $\mathrm{G}_{\mathrm{q}} / 11$ and activate phospholipase $\mathrm{C}$ in response to agonist binding (Ku et al., 1995).

During late gestation, the expression of the oxytocin receptor in the uterus is up regulated two fold, which results in a strong increase in uterine sensitivity to oxytocin (Soloff et al., 1979). After parturition, uterine oxytocin binding sites undergo a rapid 
decrease; however, oxytocin receptor expression in the mammary gland expression remained increased throughout lactation (Soloff et al., 1979; Brenton et al., 2001). Tissue specificity allows circulating oxytocin to target organs and specifically to induce milk ejection during lactation and uterine contractions during parturition.

Both ovine and bovine luteal cells synthesize oxytocin via a precursor protein similar to a protein found in the hypothalamus. Swann and colleagues (1984) collected bovine CL 5 to 10 days post-ovulation and sheep CL 3 days post-ovulation. The cells were isolated and incubated, and the hormones were detected using RP-HPLC. Oxytocinrelated components were isolated by immunoprecipitation with anti-oxytocin antiserum. Oxytocin was positively identified, via HPLC, as the hormone secreted by the ovine and bovine cells. Also, ovine cells appeared to synthesize more hormone than the bovine cells (Swann et al., 1984). Circulating concentrations of oxytocin and the patterns of its release vary during different stages of the estrous cycle. During the first 4 days after estrus, circulating oxytocin is low; at this time oxytocin stores in the old CL have been depleted, and synthesis is reinitiated in the preovulatory follicles (Wathes et al., 1993). Oxytocin release from the posterior pituitary can occur during this time of the cycle. These pulses have a duration of about 2 minutes at a frequency of 3 per hour (Gilbert et al., 1991). Oxytocin gene expression in the developing CL increases around the time of luteinization and release of oxytocin into circulation increases at this time. The concentration of oxytocin in CL rises between days 3 and 9 of the estrous cycle. In the ewe, concentrations of oxytocin increased until day 10, and a decrease was noted on that day (Jones et al., 1988; Ivell et al., 1990). However, the concentration of oxytocin began to rise again around day 14 to 15 as luteolysis was underway; at this stage estrogen is rising and 
endometrial oxytocin receptors are detected, allowing establishment of a positive feedback loop between the uterus and the ovary. Oxytocin-induced the release of prostaglandin $F_{2} \alpha$ from the uterus, which, in turn, stimulated the release of oxytocin from the regressing CL (Flint and Sheldrick, 1983).

Use of iodinated oxytocin receptor antagonists allowed researchers to localize binding sites in the reproductive tract. Endometrium, myometrium (Roberts et al., 1985; Sheldrick and Flint, 1985; Ayad et al., 1984), oviduct (Ayad et al., 1990) and cervix (Ayad et al., 1991) all contain high affinity binding sites for oxytocin. There are low affinity binding sites in the ovary. Reports based on the human oxytocin receptor sequence supported the hypothesis that binding of oxytocin to its receptor activated a Gprotein that signals through calcium channels. The resultant stimulation of phospholipase-C increases turnover of inositol phosphates (Flint et al., 1986; Ott et al., 1992). Increased turnover of inositol phosphate breaks down diacylglycerol to fatty acids, such as arachidonic acid, which is the rate-limiting precursor of prostaglandin $F_{2} \alpha$ production. Thus, increasing availability of fatty acids, more specifically arachidonic acid, allows for PG-synthase to convert arachidonic acid to prostaglandins, and increased secretion of $\mathrm{PGF}_{2} \alpha$ can be measured by its metabolite 13,14-dihydro-PGF $2 \alpha$ (PGFM). Oxytocin injections to cyclic ewes during the early and mid-luteal phase had no effect on PGFM. However, if oxytocin was injected on days 14 to 16 when estrogen was greater, an increase in PGFM was observed, with the maximum response to an injection on day 15 (Fairclough et al., 1984; Silvia et al., 1992).

Further research was conducted to determine if oxytocin receptors are located in the cervix of the ewe changed during the estrous cycle. Cervical smooth muscle was 
removed from the reproductive tract of 26 ewes during different stages of the estrous cycle, and the concentration of oxytocin receptors was determined by binding to $5 \mathrm{nmol} / \mathrm{l}$ oxytocin. Higher amounts of oxytocin receptors were found in cervical tissue only after day 15, and it peaked on the day of estrus (Matthews and Ayad, 1991).

Portions of the reproductive tract were challenged with oxytocin at different times of the estrous cycle while recording electromyographic (EMG) activity. Oxytocin injected intravenously at 25,50 and $100 \mathrm{mU}$ resulted in mean peak plasma oxytocin concentrations of 2.2, 6.4 and $8.6 \mathrm{pg} / \mathrm{ml}$ with the values returning to baseline within 10 minutes. Observed concentrations were similar to peaks occurring during a natural estrous cycle. The same procedure was conducted on ampulla, ampullary-isthmic junction, uterotubal junction, uterine horn, uterine body and cervix. The lowest dose of oxytocin, given at estrus, stimulated a response in all regions. Following estrus, the activity of the cervix and uterus was depicted by a coordinated muscle contraction that started at the cervix and proceeded to the uterotubual junction every 40 minutes. Thus, pituitary released oxytocin may regulate reproductive tract activity and could influence gamete and/or embryo transport (Garcia-Villar et al., 1982; 1983).

Knowledge of actions of oxytocin in the ovary progressed rapidly after finding ovarian oxytocin receptors in several species. In nonpregnant women, oxytocin-binding sites (Fuchs et al., 1990) and oxytocin receptor mRNA (Kimura et al., 1992) were at the highest concentration in late luteal phase. Oxytocin positive staining in the ovarian stroma and theca interna was maximal during diestrus (Zhang et al., 1991). In the cow ovary, oxytocin staining was found in the stroma and CL with peak concentrations around the time of luteolysis (Fuchs et al., 1990). Concentrations in the CL were highest 
during mid-estrous cycle (Okuda et al., 1992). Oxytocin binding to luteal membranes and ovarian stroma was low throughout the estrous cycle in sheep (Wathes et al., 1992).

Oxytocin is synthesized by the large cells of ovine CL (Rodgers et al., 1983; Jones and Flint 1988), and secretion is described as pulsatile during the luteal phase of the estrous cycle (Wathes, 1989). Swann and others (1984) demonstrated that bovine and ovine luteal cells synthesize oxytocin. The purpose of their experiment was to demonstrate how the luteal cells synthesize oxytocin by way of a precursor protein similar to one found in the hypothalamus. Bovine and ovine CL were collected, isolated and incubated with s-cysteine. Column separation and reverse-phase high performance liquid chromatography were used to determine the presence of oxytocin in luteal cell extracts. Less than 2 hours of incubation were required to recover labeled oxytocin and vasopressin. However, longer incubation showed peaks of radioactivity of both hormones. The results indicated that biosynthesis of luteal oxytocin involves the formation of a $14-\mathrm{kDA}$ precursor protein that is cleaved to form oxytocin and neurophysin. Vasopressin was found in luteal tissue of both species, however, in smaller amounts when compared to oxytocin (Swann et al., 1984).

Many conflicting roles and suggestions about oxytocin have been offered. Cultured luteal cells have provided inconsistent results, and microdialysis systems have provided a different insight into the roles of oxytocin. Exogenous oxytocin induced an acute release of progesterone, and this release was blocked by the administration of an oxytocin antagonist in the cow (Miyamoto and Schams, 1991). The response to oxytocin was related to the availability of receptors and was maximal in early luteal phase (Fuchs et al., 1990). 
Mitchell and others (1982) investigated the release of oxytocin during the ovine estrous cycle, pregnancy and parturition in mixed-breed ewes. Daily carotid artery blood samples were taken prior to beginning the experiment to determine the stage of the estrous cycle of the nonpregnant ewes. Six pregnant ewes, fitted with a jugular catheter and divided into three groups and sampled on days 122 and 124, at term pregnancy days 141 and 145 and during labor on days 146 and 148 of gestation. Of the two ewes in labor, one lambed during the sampling period and the other delivered 6 to 12 hours after the conclusion of the experiment. Oxytocin fluctuated acutely in the nonpregnant ewes during the two time periods: during the follicular phase and the early luteal phase. The pattern was more pronounced when the blood samples were collected at 1-minute intervals; oxytocin in the follicular phase was $39.2 \pm 1.5$ and $36.7 \pm 1.3(\mathrm{pg} / \mathrm{mL})$ and 68.4 \pm 2.0 and $53.1 \pm 1.6$ for the early luteal phase, with the differences between phases being significant. In the pregnant group, the average concentrations of oxytocin $(\mathrm{pg} / \mathrm{mL})$ were $17 \pm 4,8 \pm 3,22 \pm 10,22 \pm 8,28 \pm 11$, and $166 \pm 135$, respectively, as gestation progressed. The outlier in the group was the ewe that delivered during the experiment. The authors concluded that the magnitude of oxytocin increased as the ewe approached parturition (Mitchell et al., 1982).

Trophoblast interferons can suppress development of oxytocin and estradiol receptors in the ovine endometrium. Interferon tau (IFN-t) signals maternal recognition of pregnancy (maintenance of CL) in sheep and cows (Lamming et al., 1995). This mechanism was investigated in Finn-Dorset ewes with one uterine horn isolated on day 6 or 7 of their estrous cycle. The ewes were mated to a fertile or vasectomized ram and euthanized on day 13 or 16 after mating. On day 16 , there was no measurable uterine 
INF-t in the isolated horn; however, concentration of oxytocin receptors were high in both horns in ewes mated to the vasectomized rams. In ewes that conceived, a higher concentration of oxytocin receptors was found in the isolated non-pregnant horn $585 \pm$ $131 \mathrm{fmol} \mathrm{mg}^{-1}$ compared to the pregnant horn that contained $45 \pm 11 \mathrm{fmol} \mathrm{mg}^{-1 .}$ The pregnant horn expressed a significantly higher antiviral activity. Using in situ hybridization and an oxytocin antagonist, large amounts of oxytocin receptor message and binding sites were found in the endometrium of the isolated horn. Immunocytochemical studies demonstrated that there was a suppression of estradiol receptors in the pregnant horn when compared to the isolated horn. These findings indicated that INF-t plays a role in suppression of development of oxytocin and estradiol receptors in the endometrium of the pregnant ewe (Lamming et al, 1995). Further, INF-t extended luteal life span in ewes, when infused into the uterine vein (Bott et al., 2010).

Other studies have demonstrated that oxytocin in the ewe increased after day 15, and the peak concentration of oxytocin was on the day of estrus (Mathews \& Ayad, 1991; Ayad et al., 1991). These data led researchers to determine the role of progesterone and estradiol $17 \beta$ in regulation of uterine oxytocin receptors. Forty mixed breed ewes were ovariectomized and randomly placed into 8 groups. Four treatments were vehicle (corn oil) for 12 days, progesterone for 9 days, progesterone for 9 days followed by progesterone withdrawal until day 12 , and progesterone for 12 days. The second subset of four treatment groups combined the effect of progesterone with estradiol 17- $\beta$. Ewes received an intramuscular injection of progesterone or vehicle on day 1 at $0700 \mathrm{~h}$ and $1900 \mathrm{~h}$ to mimic circulating progesterone concentrations in the mid-luteal phase of the estrous cycle. Estradiol implants or blanks were implanted subcutaneously into the 
axillary region of the ewes. The ewes were euthanized on day 10 or 13 . Two other ewes were treated with an intravaginal sponge containing medroxyprogesterone acetate, and before sponge removal the ewes were injected on day 11 with $100 \mu \mathrm{g}$ of estradiol subcutaneously. A second injection of estradiol was given on day 12, and the ewes were euthanized on day 13 for tissue collection. Blood samples $(10 \mathrm{ml})$ were removed via jugular catheter daily at $1900 \mathrm{~h}$ and the last sample was removed just before the ewes were euthanized. The blood samples were analyzed for progesterone and estradiol via radioimmunoassay.

Numbers of oxytocin receptors in the caruncular and intercaruncular endometrium did not differ between the two treatments. When estradiol was not included in the treatment with progesterone (9 or 12 days), concentration of the oxytocin receptors was reduced, which was similar to the estradiol withdrawal group and the control group. The presence of estradiol reduced concentrations of oxytocin receptor in the control and both the 9- and 12-day continuous progesterone treated groups; however, it increased the number of oxytocin receptors in the progesterone withdrawal group. These findings supported past studies (Ayad and Matthews, 1991; Ayad et al., 1991) of the pattern of oxytocin receptors during the natural estrous cycle in sheep with progesterone declining at the time of luteolysis and estrogen increasing in preparation for the LH surge and ovulation (Zhang et al., 1992).

Forty-five ovariectomized Merino ewes were given exogenous progesterone and estrogen to mimic a normal estrous cycle (Lau et al., 1992). The objective of this experiment was to determine the effect of prostaglandin $F_{2} \alpha$ response and concentration of endometrial oxytocin receptors in response to progesterone. The 
ewes were placed randomly into five treatment groups, group one served as a control, group 2 was pretreated with progesterone and estrogen, group 3 was pretreated and given progesterone for 12 days from day 1 with increasing doses of progesterone from 0.5 to 12 $\mathrm{mg}$, group 4 was given $\mathrm{PGF}_{2} \alpha$ twice a day at different dosages with respect to the day; $0.5 \mathrm{mg}$ on day $10,1.0 \mathrm{mg}$ on day 11 and $2.0 \mathrm{mg}$ on day 12 . The last group received both progesterone and $\mathrm{PGF}_{2} \alpha$ at those times. In experiment 1, all ewes were given an intravenous injection of $10 \mathrm{i} . \mathrm{u}$ of oxytocin at $0900 \mathrm{~h}$ on days 13 and 14 after estrus. The concentration of the metabolite of $\mathrm{PGF}_{2} \alpha$ (PGFM) was measured when blood samples were taken at $-10,-5,5,10,20,30,45$ and 60 minutes around the time of the oxytocin injection. In the second experiment, ewes were hysterectomized on day 14, and uteri were analyzed for endometrial oxytocin receptors.

There was no detectable oxytocin-induced PGFM response to the steroid pretreatment. On day 14, the progesterone treatment alone, and the progesterone and $\mathrm{PGF}_{2} \alpha$-treated groups each gave a significantly higher response when compared to the control ewes. Binding data were derived by using a Scatchard analysis and indicated that the highest concentrations of endometrial oxytocin receptors were in the untreated ewes. Progesterone and estrogen pretreatment did not change the concentration of endometrial oxytocin receptors; however, treatment with progesterone alone or in combination with $\mathrm{PGF}_{2} \alpha$ lowered the concentration of receptors. These results translate that as $\mathrm{PGF}_{2} \alpha$ increased, number of oxytocin receptors decreased (Lau et al., 1992).

Twelve heifers were fitted with a jugular cannula or an osmotic pump. Saline or oxytocin were given by each route of administration. In a subsequent experiment, the 
heifers also received a challenge injection of oxytocin on day 16 of the estrous cycle. The objective of the experiment was to determine if a constant infusion of oxytocin would prolong the luteal phase and inhibit uterine prostaglandin $F_{2} \alpha$ secretion in heifers. The method of administration did not have an effect on estrous cycle length or the pattern of progesterone secretion. However, the estrous cycle was significantly extended by oxytocin administration $25.3 \pm 0.4$ days compared to $20.5 \pm 0.4$ days in the control group. Luteolysis did not occur in oxytocin-treated heifers until the treatment had ended. In experiment 2 , the results were similar when comparing the length of the estrous cycle; however, the challenge dose of oxytocin induced release of $\mathrm{PGF}_{2} \alpha$ in the saline-treated heifers, but not in the oxytocin-treated heifers (Lutz et al., 1991).

\section{Actions of oxytocin within the corpus luteum}

Armstrong and Hansel (1959) looked at the effect of oxytocin on the CL and progesterone production. Once daily injections of oxytocin during the first seven days shortened the diestrus phase of the cycle; however, injections of oxytocin beginning on day 15 and continued through their normal estrous cycle shortened only the subsequent estrous cycle. Corpora lutea forming after the oxytocin treatments lacked size and number of luteal cells, which lead to their diminished function. Three oxytocin injections per day for the first ten days of the estrous cycle in heifers decreased the weight of the CL collected on day 11 and also decreased serum progesterone concentrations (Simmons and Hansel, 1964). Fairclough et al. (1984) found that at the end of the estrous cycle, pulses of $\mathrm{PGF}_{2} \alpha$ were simultaneous with pulses of oxytocin, which this was also true with exogenous injections of oxytocin (Silvia and Silvia, 1989). 
Other researchers have reported that oxytocin can function as a luteolytic agent. Twice-daily subcutaneous injections of oxytocin on days four through six reduced jugular progesterone levels by day eight in cattle (Milvae and Hansel, 1980a). However, when comparing the concentrations of $\mathrm{PGF}_{2} \alpha$ in the uterine vein and ovarian artery, an increase in concentrations of $\mathrm{PGF}_{2} \alpha$ occurred in the uterine vein 30 and 240 minutes after each injection of oxytocin, but was not detected in the ovarian artery. The transport of $\mathrm{PGF}_{2} \alpha$ from the uterine vein to the ovarian artery occurs by diffusion and takes 30 minutes (McCracken et al., 1972; McCracken et al., 1981; Hixon and Hansel, 1974). However, Milvae and Hansel (1980a) detected no local transfer of $\mathrm{PGF}_{2} \alpha$ from the uterine vein to the ovarian artery in oxytocin-treated ewes. An oxytocin infusion caused an increase in the concentration of $\mathrm{PGF}_{2} \alpha$ within 30 minutes in the ovarian arteries, which remained stable for 15 minutes (Bonnin et al., 1999).

\section{$\underline{\text { Vasopressin 1A }}$}

Arginine vasopressin and oxytocin are structurally related, with only two amino acids sequences differing at the 3 and 8 positions, of a 20-membered ring. The primary role for vasopressin is regulation of renal and cardiovascular function. Antiduretic actions on kidney AVP-V2 receptors correct changes in blood osmolarity and its pressor actions on vascular smooth muscle. AVP-V1a receptors help maintain peripheral résistance under adverse conditions (Cowley, 1982; Kim et al., 1985). Hypothalamic arginine vasopressin thought via $\mathrm{V} 1 \mathrm{~b}$ receptors stimulate adrenocorticotropic hormone release from the pituitary (Antoni et al., 1984; Jard et al., 1986). Similar to oxytocin receptors, vasopressin receptor subtypes are members of the G-protein-coupled superfamily 
(Kimura et al., 1992; Morel et al., 1992; Hirsawa et al., 1994; Thibonnier et al., 1994; Rozen et al., 1995). Most arginine vasopressin V1a antagonists have been developed for treatment of hypertension and congestive heart failure (Yamamura et al., 1991).

Nine multiparous Clun Forest pregnant ewes were used to determine the amounts of oxytocin and vasopressin in blood plasma and cerebrospinal fluid (Kendrick et al., 1990). Blood samples were taken by jugular venipuncture and cerebrospinal fluid was taken from the lateral ventricle. Animals were induced into labor by an injection of dexamethasone sodium phosphate ( $20 \mathrm{mg}$ intramuscularly) on day 142 . Three to five samples were taken before contractions began, 3 to 4 samples during visible contraction, and one sample immediately following the birth of the lamb and then at 15, 30, 60, 90 and 120 minutes post-partum. Six of the nine ewes were sampled three months post parturition and 1 month after weaning. Ewes were given daily injections of estradiol benzoate for 48 hours and sampled immediately after vaginocervical stimulation. Stimulation consisted of rhythmically inserting and removing a plastic probe. Oxytocin and vasopressin concentrations were measured by radioimmunoassay.

Concentrations of oxytocin in plasma and cerebrospinal fluid were significantly greater during contractions and birth $(4.28 \mathrm{pmol} / \mathrm{l})$ than during preparturition $(1.9 \mathrm{pmol} / \mathrm{l})$. Oxytocin concentrations were 2-fold greater in the cerebrospinal fluid than in plasma. Plasma concentrations of vasopressin were significantly elevated during contractions and birth, and for 15 minutes postpartum. After five minutes of mechanical vaginocervical stimulation an increase of oxytocin and vasopressin was found in cerebrospinal fluid and plasma (Kendrick et al., 1990). 


\section{Atosiban and Barusiban}

Atosiban (ATO) or Tractocile is a mixed (V1a) and (OT) receptor competitive antagonist that has been developed for the treatment of preterm labor (PTL) contractions (UKMi, 2001). Ferring Pharmaceuticals developed this synthetic peptide in 1985 with the chemical structure being (1-deamino-D-Try(O-Et)-4-Thr-8-Orn)-Oxytocin) (Wellnitz et al., 1999). ATO was the first tocolytic developed and approved in Europe (Reinheimer, 2007; Reinheimer et al., 2005), and it has been used with less adverse side effects, such as tachycardia, vomiting, headache, chest pain, fetal tachycardia and tremors (Wex et al., 2009), than the Beta-mimetic agents (UKMi, 2001; Heus et al, 2008, 2009). The disadvantage of using ATO is the quick half-life and the rapid plasma clearance, with the initial half-life being $13 \pm 3$ minutes and the terminal half-life being $102 \pm 18$ minutes. The plasma clearance was $43 \mathrm{~L} / \mathrm{hr}$ in human patients (Goodwin et al., 1995). ATO also has been used in infertility treatments to decrease spontaneous uterine contractions that could possibly expel in-vitro fertilized embryos that are transferred to women. Pierzynski et al. (2007) infused ATO (6.75 mg bolus, 1-hour infusion at $18 \mathrm{mg} / \mathrm{h}$ and a 2-hour infusion of $18 \mathrm{mg} / \mathrm{h}$ ) during embryo transfer and successfully implanted two fertile embryos that resulted in a pregnancy. The interpretation was that ATO efficiently lowered the uterine contractions and allowed the embryos to implant instead of being expelled (Pierzynski et al., 2007).

Another tocolytic is barusiban (FE 20040), which was developed in Copenhagen, Denmark, by Ferring Pharmaceuticals. Barusiban has a 300-fold greater binding affinity for the human cloned OT receptor than for the V1a receptor (Reinheimer et al., 2005) compared to ATO. Barusiban is comparable to ATO in the lower amount of side effects 
when compared to beta-mimetic agents. Reinheimer and others (2005) concluded that both antagonists had a high efficacy, with 96 to $98 \%$ inhibition of intrauterine pressure in OT-infused cynomologus monkeys. The onset of action and efficacy of each antagonist were not different; however, the duration of action was significantly longer when infusing barusiban compared to atosiban (Reinheimer et al., 2005). The half-life of $b$ arusiban was 1.5 to $2.6 \mathrm{~h}$ compared to the 0.5 to 0.7 hours for Atosiban (Reinheimer et al., 2005).

Heus et al. (2008) found differences between treatment of ATO and ritodine in the maternal blood pressure (MBP), maternal heart rate (MHR), intra-uterine pressure or fetal heart rate (FHR). Ritodine-treated patients showed a rise in MHR while the MHR remained unaltered in the ATO-treated group. There was no significant change in the systolic or diastolic blood pressure in either group. The FHR rose in the ritodine group to $11.6 \mathrm{bpm}$ compared to the $4.9 \mathrm{bpm}$ in the ATO-treated group.

Reinheimer et al. (2007) completed the comparison between barusiban and atosiban in the cynomologus monkey. Oxytocin was given to pregnant monkeys to induce contractions and simulate pre-term labor. Atosiban and barusiban were administered intravenously with bolus or infusion to investigate changes in the response of the uterine contractions. Both antagonists had a high efficacy (96-98\%) of inhibition of intrauterine pressure and barusiban had a quicker response time being 3 to 4 times more potent than atosiban. 


\section{$\underline{\text { Statement of the problem }}$}

Research concerning ovulation, luteinization and mechanisms that control the CL has lead researchers to investigate the effect of oxytocin on the CL, primarily in sheep and cattle. Results from Armstrong and Hansel (1959) and Sheldrick et al. (1980) led researchers at West Virginia University to investigate the role of oxytocin by treatment with an antagonist directly on the ovine CL.

Mankey (2009) investigated the effects of atosiban, a combined vasopressin 1A and oxytocin receptor antagonist, delivered by an osmotic mini-pump, on the function of the ovine $\mathrm{CL}$ and the response to prostaglandin $\mathrm{F}_{2} \alpha$. Atosiban, regardless of dosage, did not alter the decrease in serum progesterone or weight of the CL after an injection of $\mathrm{PGF}_{2} \alpha$. However, progesterone appeared to decrease before the treatment with $\mathrm{PGF}_{2} \alpha$ in ewes receiving atosiban. In a second experiment, progesterone concentrations were decreased during a 48-hour sampling period when $5 \mu \mathrm{g} / \mathrm{h}$ of atosiban was continuously delivered by the mini-pump, but progesterone in CL did not decrease.

The main objective of the current experiment was to determine the effects of atosiban administered systemically. The first objective was to determine if atosiban administered in four systemic bolus injections had an effect on concentrations of serum progesterone and if the effect observed by Mankey was confirmed, to examine luteal function in more detail. Blood samples were drawn from a posterior vena cava catheter (Benoit and Dailey, 1991) every 15 minutes for 8 hours from mid-cycle (days 8 to 10) ewes. Ewes were given four intravenous injections of 0, 5, 10 or $20 \mathrm{mg}$ of atosiban. 


\section{Material and Methods}

The study was conducted in August and September 2010 on the West Virginia University Animal Science Farm. A total of 24 non-lactating ewes of predominantly Suffolk breeding were assigned at random to treatments. Ewes were fed corn silage during the estrous detection period and prior to catheterization; after catheterization the ewes were provided mixed grass hay until blood sampling. The experimental protocol was approved by the West Virginia University Animal Care and Use Committee (protocol number 08-0501).

Estrous detection began August 1 on a larger group of ewes $(n=36)$ and was continued until cycles were recorded on a sufficient number of ewes to begin the experiment. Ewes were housed in an open-sided research barn and were checked for estrus twice daily with the use of vasectomized rams, fitted with a crayon marking harness. A vasectomized ram was in constant contact with the ewes during the preexperimental period, and after ewes were marked, they were rechecked with another vasectomized ram to confirm standing estrus. Ewes were required to exhibit a complete estrous cycle of normal length ( $\sim 16$ days) prior to beginning the experiment. Ewes were between days 8 and 10 post estrus at the time the experiment was initiated. Replicates consisted of 5 to 8 ewes depending on the numbers observed in standing heat during a two-day period. After allocation into treatment groups, posterior vena cava catheters were inserted into the ewes at a depth of $65 \mathrm{~cm}$. Ewes were then housed in a smaller pen and provided with free choice water and mixed grass hay until the start of the treatments. Blood sampling and treatments were initiated approximately 12 hours after catheter placement. 
Ewes were haltered, secured to a fence in the barn period and offered water halfway through the experiment. The blood sampling began one hour before treatment and continued for nine hours, every fifteen minutes. Six mL of blood was obtained at each time point, and the catheter was flushed with heparinized saline after each sample. Blood was transferred from the syringe into a heparinized 13 x $100 \mathrm{~mm}$ disposable sample tube (Fisher Scientific) and placed on ice until plasma was removed and placed in 15 x 45 mm sample vials (Fisher Scientific, ). Vials were stored in a -20 degree freezer until further processing. Treatments consisted of four jugular injections of either $0,5,10$, $20 \mathrm{mg}$ of ATO, an hour apart over 3 hours $(0,1,2$ and 3 h). Atosiban was weighed out one day prior to the experiment and dissolved into $3 \mathrm{~mL}$ of phosphate buffered saline (PBS) for the treatment injections.

After blood sampling, the ewes were given one half hour to consume hay and water and were then placed in a dry pen for preparation for ovariectomy (OVX). Ewes were shorn and taken to the Food Animal Research Facility (FARF) for OVX; one final blood sample was obtained prior to OVX at 24 hours after the first injection of ATO. Ovaries were removed and the CL was excised and cut into four pieces and frozen. For the OVX procedure, see Foradori et al; (2005); isoflurane was used instead of halothane as an anesthetic. Ewes were observed during recovery, received post-operative antibiotic treatments at the FARF and were returned to the research barn after 24 hours.

Radioimmunoassay was performed on all plasma samples $(n=37$ per ewe) to measure concentrations of progesterone. Intra- and inter- assay coefficients of variance were $4.6 \%$ and $2.6 \%$ respectively. The standard curve ranged from 0.1 to $8.0 \mathrm{ng} / \mathrm{mL}$, and the sensitivity of the assay was $0.20 \mathrm{ng} / \mathrm{mL}$. Values for progesterone ranged from 0.2 to 
$39.8 \mathrm{ng} / \mathrm{mL}$, with most samples $<6 \mathrm{ng} / \mathrm{mL}$. Indicating that even at $65 \mathrm{~cm}$ (Benoit and Dailey, 1991 had used $56 \mathrm{~cm}$ in smaller ewes) the catheters were usually allowing sampling of blood prior to entry of ovarian drainage into the posterior vena cava.

\section{$\underline{\text { Statistics }}$}

Data for concentrations of plasma progesterone were analyzed using Proc GLM procedure (SAS Institute; Cary, NC:9:2), with $\log _{10}$ transformation of progesterone values to account for the heterogeneity of variance of the values. The model tested the effects of dose of ATO, animal within dose, and the dose by time interaction. A dose by time interaction was observed $(\mathrm{P}<0.001)$; therefore, orthogonal contrasts were made of the control $(0 \mathrm{mg})$ to the treatments $(5,10$, and $20 \mathrm{mg})$, the lower doses $(5$ and $10 \mathrm{mg})$ to the high dose $(20 \mathrm{mg})$ and the low doses $(5 \mathrm{and} 10 \mathrm{mg})$ to each other. Pre-treatment progesterone values and end of experiment weights of CL were used as covariates in the comparisons to adjust for the effects of those variables on progesterone values. Comparisons were made separately during the treatment (time 0 to 240 minutes) ( 1 hour after last treatment) and post-treatment from (greater than time 240 until the $24 \mathrm{~h}$ ).

\section{Results}

\section{Corpus Luteum Weight}

Weights of CL from ewes treated with 5 or $10 \mathrm{mg}$ of atosiban differed significantly $(\mathrm{P}<0.03)$. However, there was no significant difference between the mean CL weights of the treated ewes to the control or $20 \mathrm{mg}$ versus 5 and $10 \mathrm{mg}$ doses 
(Figure 1).

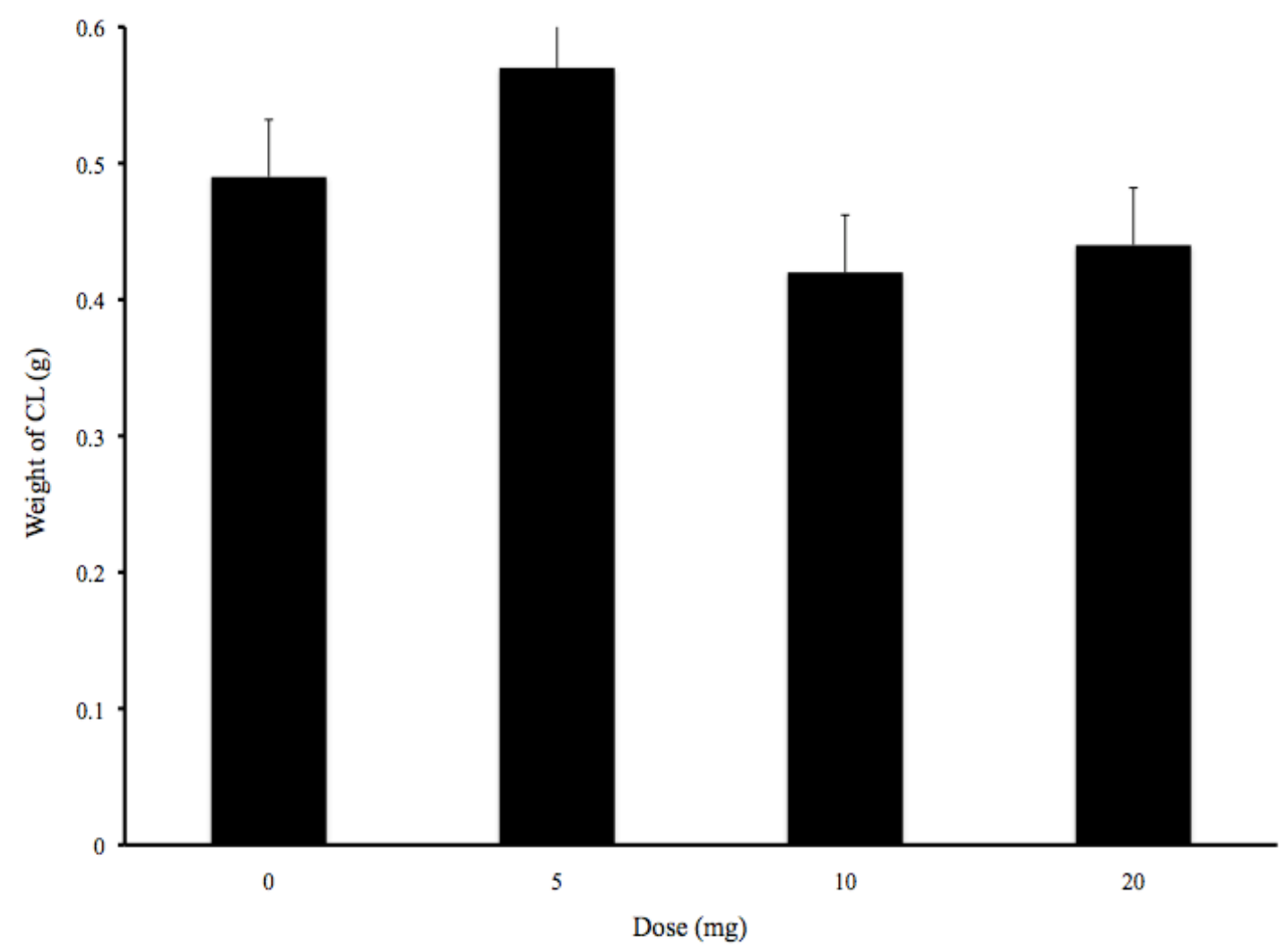

Figure 1. Mean corpus luteum weight $( \pm$ SEM) showing effect of atosiban. Bars represent treatment group means $(n=6)$ for control, 5,10 or $20 \mathrm{mg}$ of atosiban. There were significant differences the between 5 and $10 \mathrm{mg}$ dosages $(\mathrm{P}<0.03)$.

\section{$\underline{\text { Treatment phase effects on progesterone concentration }}$}

The concentrations of progesterone in the control ewes differed $(\mathrm{P}<0.0001)$ from ewes treated with 5,10 or $20 \mathrm{mg}$ of atosiban. In addition concentrations of progesterone differed between the $20 \mathrm{mg}$ dose and the 5 and $10 \mathrm{mg}$ doses together $(\mathrm{P}<$ 0.05 , Figure 2). 


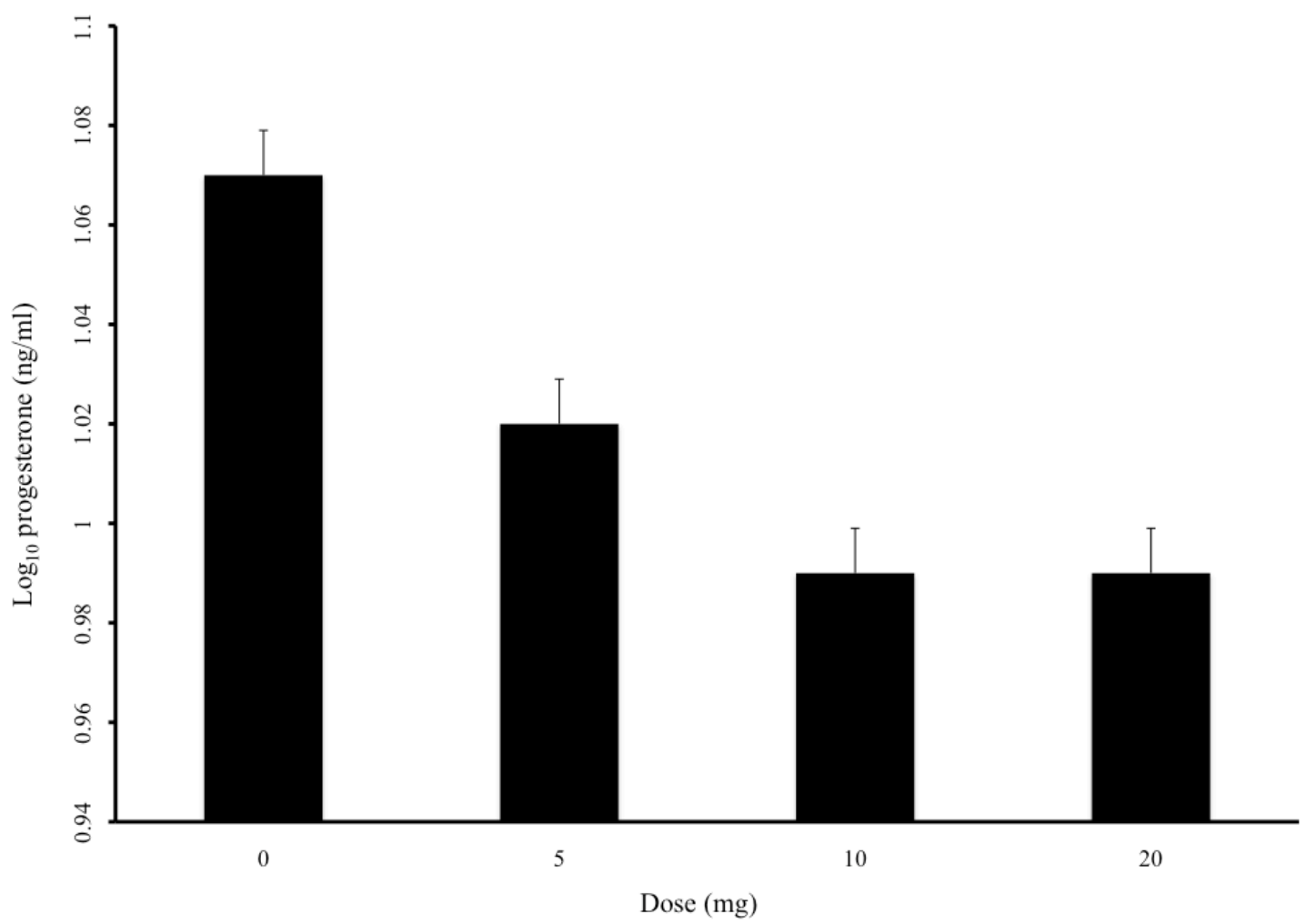

Figure 2. Mean $\log _{10}$ concentrations of progesterone $( \pm$ SEM). Bars represent treatment group means $(\mathrm{n}=6)$ for control, 5,10 or $20 \mathrm{mg}$ of atosiban. There was a significant difference between ewes treated $(5,10$ or $20 \mathrm{mg})$ with atosiban to control ewes $(\mathrm{P}<$ $0.0001)$ also when comparing the $20 \mathrm{mg}$ dose to the 5 and $10 \mathrm{mg}$ doses $(\mathrm{P}<0.05)$.

Considered together, these comparisons show that there was a decrease in the mean progesterone for ewes treated with 5, 10 or $20 \mathrm{mg}$ of atosiban compared to the control mean. However, when comparing the treatment groups, 10 and $20 \mathrm{mg}$ of atosiban decreased the mean progesterone concentrations when compared to the control and the 5 $\mathrm{mg}$ dose. The 10 and $20 \mathrm{mg}$ dosages of atosiban were the most effective in lowering progesterone concentration compared to the other treatments during this interval of the experiment. 


\section{$\underline{\text { Post treatment effects on progesterone concentration }}$}

There were differences during this time interval comparing the controls to all treated groups $(\mathrm{P}<0.005)$, and ewes treated with $20 \mathrm{mg}$ versus 5 and $10 \mathrm{mg}(\mathrm{P}<0.05$,

Figure 3).

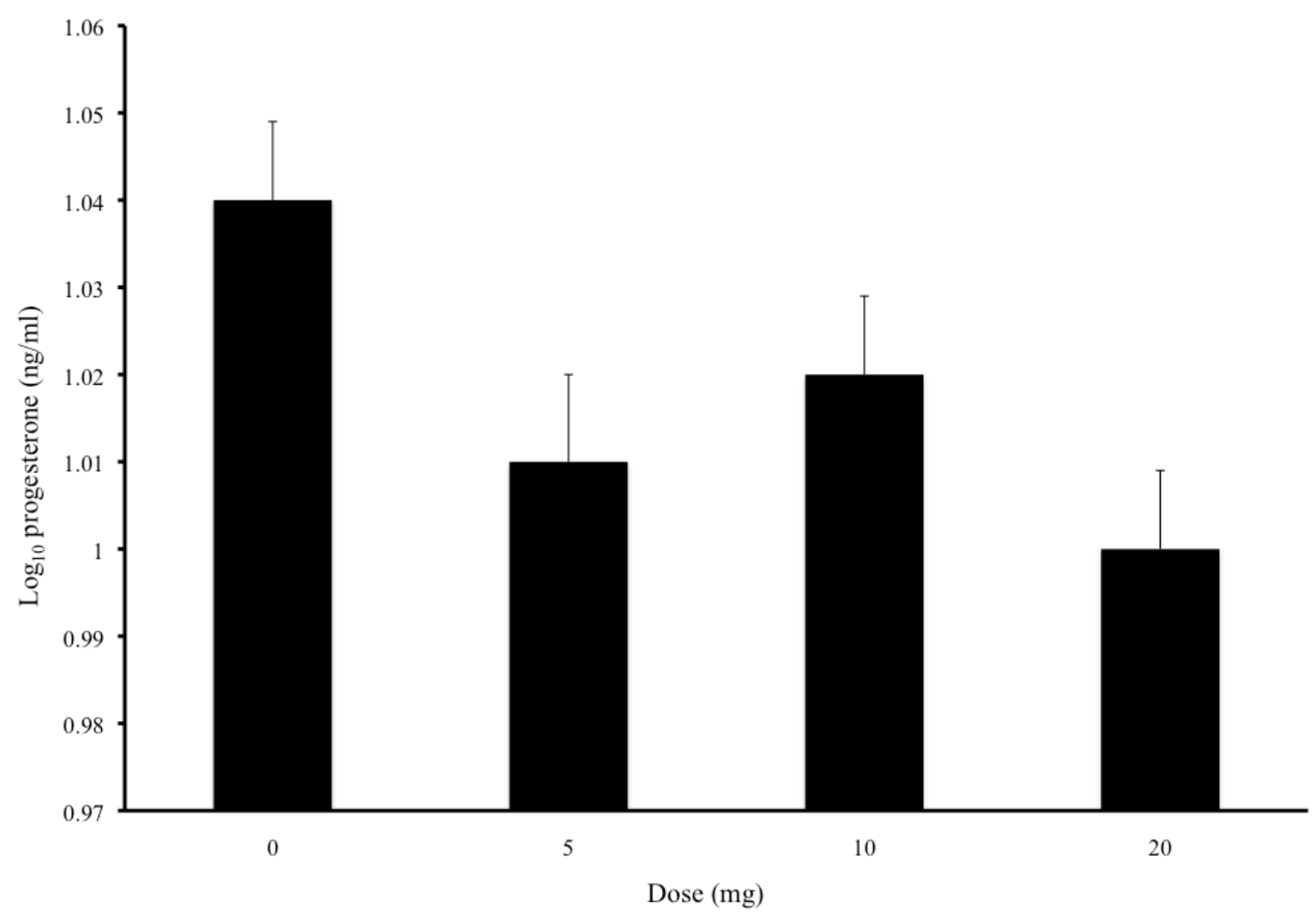

Figure 3. Mean $\log _{10}$ concentrations of progesterone $( \pm$ SEM). Bars represent treatment group means $(n=6)$ for control, 5,10 or $20 \mathrm{mg}$ of atosiban. There were significant differences for control versus treatment ( $0 \mathrm{mg}$ vs 5, 10 and $20 \mathrm{mg})(\mathrm{P}<0.005)$, and between the high dose versus the lower dosages $(20 \mathrm{mg}$ vs 5 and $10 \mathrm{mg})(\mathrm{P}<0.05)$.

During this time interval the mean $\log _{10}$ progesterone concentration of the control ewes decreased (1.04) compared to the treatment interval (1.07). There was an increase (1.02 vs. 0.99$)$ in the mean $\log _{10}$ progesterone concentrations of the ewes treated with 10 mg of atosiban. Values for the 5-, 10- and 20-mg-treated groups were lower than those in 
the control ewes during the post-treatment period. The lowest progesterone concentration was seen in the group treated with $20 \mathrm{mg}$ of atosiban.

\section{Overall effect of dose on progesterone concentration}

When analyzing the overall effect of atosiban on progesterone concentrations from time 0 until the end of the experiment, there was a significant difference when comparing the control ewes to the ewes treated with $(5,10$ or $20 \mathrm{mg})$ of atosiban $(\mathrm{P}<$ 0.0001 , Figure 4).

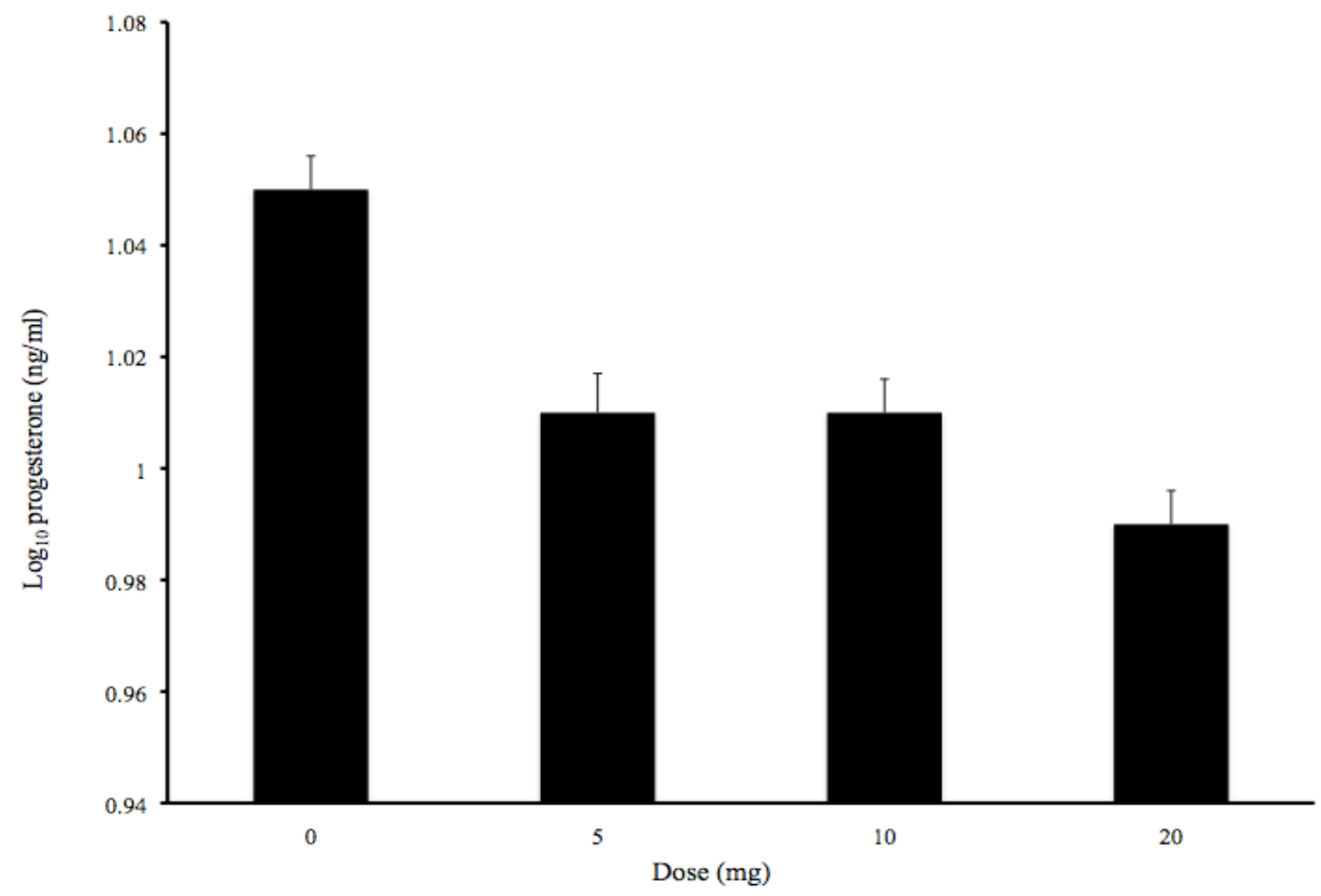

Figure 4. Mean $\log _{10}$ concentrations of progesterone $( \pm$ SEM). Bars represent treatment group means $(\mathrm{n}=6)$ for control, 5,10 or $20 \mathrm{mg}$ of atosiban. There were significant differences for control versus treatment $(0 \mathrm{mg}$ vs 5,10 and $20 \mathrm{mg})(\mathrm{P}<0.0001)$. 


\section{Discussion}

The major hormone in reproduction and the maintenance of pregnancy is progesterone (Murphy, 2000), produced by the CL. Current research is centered around progesterone production, CL lifespan, and endocrine/exocrine factors that control the CL. One factor proposed to affect progesterone production is oxytocin. Atosiban is a combined oxytocin and vasopressin receptor antagonist, which was used in this experiment to test the proposed mechanisms by which oxytocin might influence progesterone secretion as measured by its concentration in the posterior vena cava of ewes. Intravenous injections of atosiban had a significant effect on $\log _{10}$ concentrations of progesterone, both during and after treatment. There were similar effects during and after treatment $\log _{10}$ concentrations of progesterone. Mean progesterone concentrations were reduced in ewes treated with $(5,10$ or $20 \mathrm{mg})$ atosiban compared to the control ewes. The observed reduction in progesterone fits with the earlier study by Mankey (2009), who infused atosiban directly into the CL. Thus, the current data confirmed the hypothesis that atosiban reduced the progesterone in response to treatment.

During the post treatment phase there was a decrease in the progesterone in the control ewes and an increase in the concentration of progesterone in ewes treated with 10 mg of atosiban compared to during treatment. However, mean progesterone concentrations for all treated groups remained lower post treatment than in the control group. Nevertheless, there was a rebound in the concentration of progesterone from suppression by atosiban in ewes treated with $10 \mathrm{mg}$. 
Atosiban has been found to be a "biased agonist" when cultured with human oxytocin receptors (Reversi et al., 2005). Human oxytocin receptors have been shown to associate to $G_{q}, G_{i}$ and $G_{s}$ proteins (Strakova \& Soloff, 1997). Coupling to $G_{q}$ is responsible for phospholipase $\mathrm{C}$ activation, which is responsible for increased intracellular calcium (Sanborn, 2001). Atosiban acted as a competitive antagonist on the oxytocin receptor/ $\mathrm{G}_{\mathrm{q}}$ coupling and displayed agonistic properties on the $\mathrm{OTR} / \mathrm{G}_{\mathrm{i}}$ pathway, but no effects on the OTR/G $/ \mathrm{G}_{\text {s }}$ pathway. However, atosiban lead to persistent ERK1/2 activation and $\mathrm{p}^{21}$ induction and inhibited oxytocin-cell growth in kidney cells and prostate cells infected with oxytocin receptors (Reversi et al., 2005).

Similar to atosiban, oxytocin has demonstrated two different mechanisms of action. A low concentration of $4 \mathrm{i} . \mathrm{u} / \mathrm{mL}$ oxytocin stimulated progesterone production when cultured with $10 \mathrm{i} . \mathrm{u} / \mathrm{mL}$ of hCG on human luteal cells (Tan et al., 1982). However, 400 or $800 \mathrm{i} . \mathrm{u} / \mathrm{mL}$ of oxytocin inhibited progesterone production in the same system. In contrast, Richardson and Masson (1985) incubated bovine luteal cells with $10 \mathrm{i} . \mathrm{u} / \mathrm{mL}$ of hCG and $500 \mathrm{i} . \mathrm{u} / \mathrm{mL}$ of oxytocin and progesterone production was not inhibited.

Lutz and others (1991) used mini-pumps or jugular infusions of oxytocin to the CL beginning on day 10 and observed lengthened diestrus as a result of prolonged progesterone secretion. In saline-infused heifers normal $\mathrm{PGF}_{2} \alpha$ secretion occurred on day 16 in response to a challenge injection of oxytocin. These results demonstrated that chronic oxytocin treatment inhibited episodic pulses of $\mathrm{PGF}_{2} \alpha$. Miyamoto and Schams (1991) utilized a microdialysis system in bovine CL and found that the combination of bovine LH and oxytocin stimulated progesterone secretion in a dose dependent manner. The greatest effect was found on day 5 of the estrous cycle and was found to decrease 
from day 8 to 18 . Their overall interpretation of the results was that cell-to-cell interactions were needed for progesterone to be stimulated by oxytocin (Miyamoto and Schams, 1991).

Atosiban could have vasoconstrictive properties, which was not measured in the experiment. In the previous study (Mankey, 2009) did not find a difference in luteal progesterone, but found a difference in circulating concentrations of progesterone. Oxytocin has been found to be a vasoconstrictor in rats (Altura and Altura, 1977). Another source of vasoconstriction could be from arginine vasopressin activation, which is a known vasocontrictor (Du Vigneaud et al., 1953). Bovine CL produced arginine vasopressin (Wathes et al., 1983). When porcine and bovine luteal cells were cultured separately with either oxytocin or vasopressin; the vasopressin was more effective at reducing progesterone concentrations than oxytocin (Pitzel et al., 1988).

In general, the roles of oxytocin are not fully understood in any species. This uncertainty is further displayed by the previous experiment conducted by Mankey (2009). When atosiban was delivered directly into the $\mathrm{CL}$ via a mini-osmotic pump it appeared to decrease progesterone. However, there was not a significant difference among doses of atosiban in progesterone concentrations after an injection of $\mathrm{PGF}_{2} \alpha$. In a second experiment, the negative effect of atosiban on progesterone was confirmed. Progesterone concentrations were decreased significantly during the 48-hour sampling period when 5 $\mu \mathrm{g} / \mathrm{h}$ of atosiban was continuously delivered via mini-pump.

The results of the current study are similar to those found by Mankey (2009). A reduction in the concentration of progesterone in ewes treated with atosiban was found in 
both studies. The differences in dose and route of administration did not appear to alter the outcome of the present study. The previous study used an osmotic-mini-pump to deliver the atosiban directly into the $\mathrm{CL}$ and delivered the doses constantly for 14 days. However, in the current study, the treatments were delivered via bolus intravenous injections every hour for four hours beginning with time zero and stopping at time 180 minutes. When comparing the dose amounts from the two experiments, the previous experiment used a lower amount of atosiban than did the current experiment. The increased dose was chosen on the basis of human research in which was used to halt uterine contractions.

The "biased agonist" theory could be used to explain the results from this experiment. Perhaps one dose of atosiban can be an agonist while another dose can be an antagonist. During the treatment phase of the experiment, progesterone decreased in the treated groups. Only in the $10 \mathrm{mg}$ group, progesterone increased in the post treatment phase compared to the treatment phase. The degree of progesterone suppression was less in the post treatment period in the ewes treated with $10 \mathrm{mg}$ of atosiban compared to the ewes treated with 5 or $20 \mathrm{mg}$. The present results, are similar to those of Mankey (2009) in terms of the overall the reduction in progesterone concentrations.

\section{Conclusion}

The main conclusion from this experiment is that atosiban reduced circulating concentrations of progesterone. Examination of the mechanism for this effect will require measurements of blood flow, in view of the observation by Mankey (2009) that 
progesterone in the CL did not change. It also will be appropriate to examine changes in steroidogenic genes in the large and small luteal cells. 


\section{Literature Cited}

Adelmann, H.B. 1966. Marcello Malpighi and the Evolution of Embryology. Cornell University Press. Ithaca, NY.

Albrecht, B.A., J.N. MacLeod and P.F. Daels. 2001. Expression of 3 beta-hydroxysteroid dehydrogenase, cytochrome P450 aromatase enzymes in corpora lutea of diestrous and early pregnant mares. Theriogenology 55:551-561.

Alila, H.W. and W. Hansel. 1984. Origin of different cell types in the bovine corpus luteum as characterized by specific monoclonal antibodies. Biol. Reprod. 31:1015-1025.

Altura, B.M. and B.T. Altura. 1977. Vascular smooth muscle and neurohypophyseal hormones. Fed Proc. 36:1853-1960.

Antoni, F.A. 1984. Characterization of high affinity binding sites for vasopressin in bovine adrenal medulla. Neuropeptides 4:413-420.

Armstrong, D.T. and J.H. Dorrington. 1977. Estrogen biosynthesis in the ovaries and testis. In Regulatory Mechanisms Affecting Gonadal Hormone Action. 215-258. University Park Press, Baltimore.

Armstrong, D.T. and W. Hansel. 1959. Alterations of the bovine estrous cycle with oxytocin. J. Dairy Sci. 42:533-542.

Asdell, S.A. 1964. Patterns of Mammalian Reproduction. Cornell University Press. Ithaca, NY.

Attardi, B., G.R. Marshall, D.S. Zorub, S.J. Winters, J. Miklos and T.M. Plant. 1992. Effects of orchidectomy on gonadotropin and inhibin subunit messenger ribonucleic acids in the pituitary of the rhesus monkey (Macaca mulatta). Endocrinology 130:1238-1244.

Attardi, B., J. Vaughan and W. Vale. 1992. Regulation of FSH beta messenger ribonucleic acid levels in the rat by endogenous inhibin. Endocrinology 130:557-559.

Ayad, V.J. and D.C. Wathes. 1989. Characterization of endometrial and myometrial oxytocin receptors in the non-pregnant ewe. J. Endocrinol. 123:353-359.

Ayad, V.J., C.L. Gilbert, S.A. McGoff, E.L. Matthews and D.C. Wathes. 1994. Actions of oxytocin and vasopressin on oestrogen-induced electromyographic activity recorded from the uterus and oviduct of anoestrous ewes. Reprod. Fertil. Dev. 6:203-209. 
Ayad, V.J., S.E.F. Guldenaar and D.C. Wathes. 1991. Characterization and localization of oxytocin receptors in the uterus and oviduct of the non-pregnant ewe using an iodinated receptor antagonist, J. Endocrinol. 128:353-359.

Ayad, V.J., E.L. Matthews, D.C. Wathes, T.J. Parkinson and M.L. Wild. 1991. Autoradiographic localization of oxytocin receptors in the endometrium during the oestrous cycle of the ewe. J. Endocrinol. 130:199-206.

Ayad, V.J., S.A. McGoff and D.C. Wathes. 1990. 0xytocin receptors in the oviduct during the oesterous cycle of the ewe. J. Endocrinol. 124:353-359.

Baird D.T., T.G. Baker, K.P. McNatty and P. Neal. 1975. Relationship between the secretion of the corpus luteum and the length of the follicular phase of the ovarian cycle. J. Reprod. Fertil. 45:611-619.

Barta, S. 1986. Effect of estrogen and progesterone treatment on calcium uptake by the myometrium and smooth muscle of the lower urinary tract. Eur. J. Pharmacol. 127:37-42.

Beal, W.E., J.H. Lukaszewska and W. Hansel. 1981. Luteotropic effects of bovine blastocysts. J. Anim Sci. 52:567-574.

Beard, J. 1897. The Span of Gestation and the Cause of Birth. Fischer, Jena, Germany.

Benoit, A.M. and R.A. Dailey. 1991. Catheterization of the caudal vena cava via the lateral saphenous vein in the ewe, cow, and gilt: an alternative to utero-ovarian and medial coccygeal vein catheters. J. Anim. Sci. 69:2971-2979.

Bindon, B.M., M.R. Blanc, J. Pelletier, M. Terqui and J. Thimonier. 1979. Periovulatory gonadotrophin and ovarian steroid patterns in sheep of breeds with differing fecundity. J. Reprod. Fertil. 55:15-25.

Bonnin P., L. Huynh, T.L. Haridon, N. Chene and J Martal. Transport of uterine PGF2a to the ovaries by systemic circulation and local lymphovenous-arterial diffusion during luteolysis in sheep. J. Reprod. Fertil. 116:199-210.

Borowczyk, E., M.L. Johnson, J.J. Bilski, M.A. Bilska, D.A. Redmer, L.P. Reynolds and A.T. Grazul-Bilska. 2007. Role of gap junction in regulation of progesterone secretion by ovine luteal cells in vitro. Society of Reproduction and Fertility. 133:641-651.

Bott, R.C., R. L. Ashley, L.E. Henkes, A.Q. Antoniazzi, J.E. Bruemmer, G.D. Niswender, F.W. Bazer, T.E. Spencer, N.A. Smirnova, R.V. Anthony and T.R. Hansen. 2010. Uterine infusion of interferon Tau (IFNT) extends luteal life span in ewes. Biol. Reprod. 82:725-735. 
Bottari, S.P., A. Vokaer, E. Kaivez, J.P. Lescrainier and G.P. Vauquelin. 1983. Differential regulation of alpha-adrenergic receptor subclasses by gonadal steroids in human myometrium. J. Clin. Endocrinol. Metab. 57:937-941.

Bowen-Shauver, J.M. and G. Gibori. 2004. The corpus luteum of pregnancy, In The Ovary. 201-230. Elsevier Academic Press, San Diego.

Brenner, R.M., J.A. Resko and N.B. West. 1974. Cyclic changes in oviductal morphology and residual cytoplasmic estradiol binding capacity induced by sequential estradiol--progesterone treatment of spayed Rhesus monkeys. Endocrinology 95:1094-104.

Breton, C., H. Chellil, M. Kabbaj-Benmansour, E. Carnazzi, R. Seyer, S. Phalipou, D. Morin, T. Durroux, H. Zingg, C. Barberis and B. Mouillac. 2001. Direct identification of human oxytocin receptor-binding domains using a photoactivatable cyclic peptide antagonist: comparison with the human Via vasopressin receptor. J. Bio. Chem. 276:26931-26941.

Chedrese, P.J., V. Luu-The and F. Labrie. 1990. Evidence for the regulation of 3Bhydroxysteroid dehydrogenase messenger RNA by human chorionic gonadotropin in luteinized porcine granulosa cells. Endocrinology 126:2228-2230.

Concannon, P.W. 1886. Canine pregnancy and parturition. Vet Clin North Am Small Anim Pract. 16:453-75.

Cooke, R.G. and N. Ahmad. 1994. Prostaglandin F2 alpha induced release of oxytocin from ovine corpora lutea in vitro. Prostaglandins. 48:257-261.

Corner G.W. 1937. The rate of secretion of progestin by the corpus luteum. Cold Spring Harbour Symposia on Quantitative Biology. 5:62.

Cowley Jr, A.W. 1982. Vasopressin and cardiovascular regulation. Int. Rev. Physiol. $26: 189-242$.

Cran, D.G. 1983. Follicular development in the sheep after priming with PMSG. J. Reprod. Fertil. 67:415-423.

Cummings, A.M. and J.M. Yochim. 1984. Differentiation of the uterus in preparation for gestation: a model for the action of progesterone. J. Theor. Biol. 106:353-374.

Cunningham, N.F., A.M. Symons and N. Saba. 1975. Levels of progesterone, LH and FSH in the plasma of sheep during the oestrous cycle. J Reprod. Fertil. 45:177180.

De Graaf, R. 1672. De Mulierum Organis Generationi Inservientibus Tractatus Novus. Lungduni Batax., Ex Officina Hackiana. 
Del Vecchio, R.P., J.K. Thibodeaux and W. Hansel. 1994. Interactions between large and small bovine luteal cells in a sequential perfusion co-culture system. J. Anim. Sci. 72:963-968.

Denamur, R., J. Martinet and R.V. Short. 1973. Pituitary control of the ovine corpus luteum. J Reprod Fertil. 32:207-220.

Di Zergega, G.S. and G.D. Hodgen. 1981. Folliculogenesis in the primate ovarian cycle. Endocr. Rev. 2:27-49.

Donaldson, L.E. and W. Hansel. 1965 The luteotropic properties of luteinizing hormone and the nature of oxytocin-induced luteal inhibition. J. Dairy Sci. 48:331.

Douglas, R.H. and O.J. Ginther. 1973. Luteolysis following a single injection of prostaglandin F2a in sheep. J. Anim. Sci. 37:990-993.

Duggavathi, R. and B.D. Murphy. 2009. Ovulation signals. Science, 324:890-891.

Du Vigneaud, V. 1956. Trail of sulfur research: From Insulin to oxytocin. Science 123:967-974.

Du Vigneaud, V., C. Ressler and S. Trippett. 1953. The sequence of amino acids in oxytocin, with a proposal for the structure of oxytocin. J. Biol. Chem. 205:949957.

Eckstein, P. and Zuckerman, S. 1956. The oestrous cylce in the mammalia. In Marshall's Physiology of Reproduction. A.S. Parkes, Ed. 226-396. Longmans Green, New York.

Fabricius, H.B. 1604. De Formato Foetu. Patavii; L Pasquati, Padua, Italy.

Fairchild, D.L. and J.L. Pate. 1989. Interferon-gamma induction of major histocompatibility complex antigens on cultured bovine luteal cells. Biol Reprod. 40:453-457.

Fairclough, R.J., L.G. Moore, A.J. Peterson and W.B. Watkins. 1984. Effect of oxytocin on plasma concentrations of 13,14-dihydro-15-keto-prostaglandin $\mathrm{F}$ and the oxytocin-associated neurophysin during the oestrous cycle and early pregnancy in the ewe. Biol. Reprod. 31:36-43.

Farin, C.E., C.L Moeller, H.R. Sawyer, F. Gamboni and G.D. Niswender. 1986. Morphometric analysis of cell types in the ovine corpus luteum throughout the estrous cycle. Biol. Reprod. 35:1299-1308.

Fields, M.J. and P.A. Fields. 1996. Morphological characteristics of the bovine corpus luteum during the estrous cycle and pregnancy. Thereiogenology. 45:1295-1239. 
Fields, P.A.1991. Relaxin and other secretory peptides: cell localization and function in the ovary. In: Familiari, G., Makabe, S., Motta, P.M. (Eds), Ultrastructure of the Ovary. Kluwer Academic Press, Boston pp 177-198.

Fitz, T.A., M.H. Mayan, H.R. Sawyer and G.D. Niswender. 1982. Characterization of two steriodgenic cell types in the ovine corpus luteum. Biol Reprod. 27:703-711.

Flint, A.P.F. and E.L. Sheildrick. 1983. Evidence for a systemic role for ovarian oxytocin in luteal regression in sheep. J. Reprod. Fertil. 67:215-225.

Flint, A.P.F., W.M. Leat, E.L. Sheldrick and H.J. Stewart. 1986. Stimulation of phoshoinositide hydrolysis by oxytocin and the mechanism by which oxytocin controls prostaglandin synthesis in the ovine endometrium. J. Biochem. 237:797805.

Foradori, C.D., R.L. Goodman, V.L. Adams, M. Valent and M.N. Lehman. 2005. Progesterone increases dynorphin a concentrations in cerebrospinal fluid and preprodynorphin messenger ribonucleic acid levels in a subset of dynorphin neurons in the sheep. Endocrinology 146:1835-1842.

Fortune, J.E. 1994. Ovarian follicular growth and development in mammals. Biol. Reprod. 50:225-232.

Fraenkel, L. 1903. Die function des corpus luteum. Arch Gynaekol. 20:461-466.

Freeman, M.E. 2006. Neuroendocrine control of the ovarian cycle of the rat. In Knobil and Neill's Physiology of Reproduction. 2327-2388. Academic Press, St. Louis.

Fritz, M.A. and T.A. Fitz. 1991. The functional microscopic anatomy of the corpus luteum: the small cell-large cell controversy. Clin Obstet. Gynecol. 32:144.

Fuchs, A.R., O. Behrens, H. Helmer, A. Vangsted, M. Ivanisevic, J. Grifo, C. Barros and M. Fields. 1990. Oxytocin and vasopressin binding sites in human and bovine ovaries. Am. J. Obstet. Gynecol. 163:1961-1967.

Garcia-Villar, R., P.L. Toutman, J. More and Y. Ruckerbusch. 1982. Spontaneous motility of the cervix in cyclic and ovariectomised ewes and changes induced by exogenous hormones. J. Reprod. Fertil. 66:317-326.

Garcia-Villar, R., P.L. Toutman, D. Schams and Y. Ruckerbusch. 1983. Are regular activity episodes of the genital tract controlled by the pulsatile release of oxytocin? Biol. Reprod. 29:1183-1188.

Gévry, N., D. Lacroix, J.H. Song, N. Pescador, M. Dobias and B.D. Murphy. 2002. Porcine Niemann Pick-C1 protein is expressed in steroidogenic tissues and modulated by cAMP. Endocrinology 143:708-716. 
Gévry, N.Y. and B.D. Murphy. 2002. The role and regulation of the Niemann-Pick C1 gene in adrenal steroidogenesis. Endocrine Res. 28:403-412.

Gibori, G., I. Khan, M. Warshaw, M.P. McLean, T.D. Purhear, S. Nelson, T.J. Durkee, S. Azhar, A. Steinschneider and M.C. Rao. 1988. Placental derived regulators and the complex control of luteal cell function. Recent Prog Horm Res. 44:377-429.

Gilbert, C.L., K. Jenkins and D.C. Wathes. 1991. Pulsatile release of oxytocin into the circulation of the ewe during oestrus, mating and the early luteal phase. J. Reprod. Fertil. 91:337-346.

Gimple, G. and F. Fahrenholz. 2001. The oxytocin receptor system: structure, function, and regulation, Physiol. Rev. 81:629-683.

Goodman R.L and E.K. Inskeep. 2006. Neuroendocrine control of the ovarian cycle of the sheep. In Knobil and Neill's Physiology of Reproduction. 2389-2447. Academic Press, St. Louis.

Grazul-Bilska, A.T., L.P. Reynolds and D.A. Redmer. 1997a. Gap junctions in the ovaries. Biol. Reprod. 57:947-957.

Grazul-Bilska, A.T., D.A. Redmer and L.P. Reynolds. 1997b. Cellular interactions within the corpus luteum. Seminars in Reprod. Endocrinol. 15:383-393.

Grazul-Bilska, A.T., L.P. Reynolds, J.J. Bilski and D.A. Redmer. 2001. Effects of second messenger on gap junctional intracellular communication of ovine luteal cells throughout the estrous cycle. Biol. Reprod. 65:777-783.

Greenstein, J.S., R.W. Murray and R.C. Foley. 1958. Observations on the morphogenesis and histochemistry of the bovine preattachment placenta between 16 and 33 days of gestation. Anat. Rec.132(3):321-341.

Hansel, W., P.W. Concannon and J.H. Lukaszewska. Corpora lutea of the large domestic animals. Biol. Reprod. 8:222-245.

Heape, W. 1900. The "sexual season"of mammals and the relation of the "pro-oestrum" to menstruation. Q. J. Microsc. Sci. 44:1-70.

Heus, R.D., B.W. Mol, Jan-Jaap H.M. Erwich, H.P. van Geijn, W.J. Gyselaers, M. Hanssens, L. Harmark, C.D. van Holsbeke. J.J. Duvekot, F.F.A.M. Schobben, H. Wolf and G.H.A. Visser. 2009. Adverse drug reactions to tocolytic treatment for preterm labour: prospective cohort study. BMJ. 338:1-6.

Heus, R.D., J.H. Eduard Mulder, J.B. Derks, H.J. Peit Kurver, L van Wolfswinkel and H.A. Gerard Visser. 2008. A prospective randomized trial of actute tocolysis in term labour with atosiban or ritodine. European J. Obstet. Gynecol. Reprod. Biol. 139:139-145. 
Hilliard, J. 1973. Corpus luteum function in guinea pigs, hamsters, rats, mice and rabbits. Biol. Reprod. 8:203-221.

Hirasawa, A., K. Shibata, K. Kotosai and G, Tsujimoto. 1994. Cloning, functional expression and tissue distribution of human cDNA for the vascular-type vasopressin receptor. Biochem. Biophys. Res. Commun. 203:72-79.

Hixon, J.E. and W. Hansel. 1974. Evidence for preferential transfer of prostaglandin F2a to the ovarian artery following intrauterine administration in cattle. Biol. Reprod. 11:543-552.

Hoffman, B., D. Barth and H. Karg. 1978. Progesterone and estrogen levels in perpipheral plasma of the pregnant and nonpregnant roe deer (Capreolus capreolus). Biol. Reprod. 19:931-935.

Hoyer, P.B., P.L Keyes and G.D. Niswender. 1998. Steroidogenic capacity and ultrastructural morphology of cultured ovine luteal cells. Biol. Reprod. 38:909920.

Ing, N.H. and M.B. Tornesi. 1997. Estradiol up-regulates estrogen receptor and progesterone receptor gene expression in specific ovine uterine cells. Biol Reprod. $56: 1205-1215$.

Ivell, R., N. Hunt, N. Abend, B. Brackman, D. Nollmeyer. J.C. Lamsa and J.A. McCracken. 1990. Structure and ovarian expression of the oxytocin gene in sheep. Reprod. Fertil. Development 134:409-411.

Iwai, M., H. Kanzaki, M. Fujimoto, K. Kojima, H. Hatayama, T. Inoue, T. Higuchi, H. Nakayama, T. Mori and J. Fujita. 1995.Regulation of sex steroid receptor gene expression by progesterone and testosterone in cultured human endometrial stromal cells. J. Clin. Endocrinol. Metab. 80:450-454.

Jablonka-Shariff, A., A.T. Grazul-Bilaska, D.A. Redmer and L.P. Reynolds. 1993. Growth and cellular proliferation of ovine corpora lutea throughout the estrous cycle. Endocrinology 133:1871-1879.

Jard, S., R.C. Gaillard, G. Guillon, J. Marie, P. Schoenenberg, A.F. Muller, M. Manning and W.H. Sawyer. 1986. Vasopressin antagonists allow demonstration of a novel type of vasopressin receptor in the rat adenohypophysis. Mol. Pharmacol. 30:171-177.

Jeungel, J.L., H.A. Garverick, A.L. Johnson, R.S. Youngquist and M.F. Smith. 1993. Apoptosis during luteal regression in cattle. Endocrinology 132:249-254. 
Juengel, J.L., H.R. Sawyer, P.R. Smith, L.D. Quirke, D.A. Heath, S. Lun, S.J. Wakefield and K.P. McNatty. 2002. Origins of follicular cells and ontogeny of steroidogenesis in ovine fetal ovaries. Mol. Cell. Endocrinol. 191:1-10.

Jones, D.S.C. and A.P.F Flint. 1988. Concentrations of oxytocin-neurophysin prohormone mRNA in corpora lutea of sheep during the oesterous cycle and in early pregnancy. J. Endocrinol. 117:409-414.

Kaltenbach, C.C., B. Cook, G.D. Niswender and A.V. Nalbandov. 1967a. Effect of pituitary hormones on progesterone synthesis by ovine luteal tissue in vitro. Endocrinology. :1407-9.

Kaltenbach, C.C., J.W. Graber, G.D. Niswender and A.V. Nalbandov. 1968a. Effect of hypophysectomy on the formation and maintenance of corpora lutea in the ewe. Endocrinology 82:753-759.

Kaltenbach, C.C., J.W. Graber, G.D. Niswender, and A.V. Nalbandov. 1968b. Luteotrophic properties of some pituitary hormones in nonpregnant or pregnant hypophysectomized ewes. Endocrinology. 82:818-24.

Kaneko, H, Y. Nakanishi, K. Taya, H. Kishi, G. Watanabe, S. Sasamoto and Y. Hasegawa. 1993. Evidence that inhibin is an important factor in the regulation of FSH secretion during the mid-luteal phase in cows. J. Endocrinol. 136:35-41.

Karsch, F.J., J.W. Noveroske, J.F. Roche, H.W. Norton and A.V. Nalbandov. 1970. Maintenance of ovine corpora lutea in the absence of ovarian follicles. Endocrinology 87:1228-1236.

Kawai, Y. and M.R. Clark. 1986. The mechanisms by which phorbol ester inhibits LH stimulation of progesterone production in rat granulosa cells. Endocrinol. Res. 12:195-209.

Kendrick, K.M. 1990. Microdialysis measurement of in vivo neuropeptide release. J. Neurosci. Methods. 34:35-46.

Kenny, N., C.E. Farin and G.D. Niswender. 1989. Morphometric quantification of mitochondria in the two steroidogenic ovine luteal cell types. Biol. Reprod. 40:191-196.

Kim, J.K., M.A. Dillingham, S.N. Summer, S. Ishikawa, R.J. Anderson and R.W. Schrier. 1985. Effects of vasopressin antagonist on vasopressin binding, adenylate cyclase activation, and water flux. J. Clin. Invest. 76:1530-1535.

Kimura, T.O., K. Tanizawa, M. Mori, M.J. Brownstein and H. Okayama. 1992. Structure and expression of a human oxytocin receptor. Nature 356:526-529. 
Kimura, T., K. Ota, M. Shoji, M. Inoue, K. Sato, M. Ohta, T. Yamamoto, Y. Shimizu and K. Yoshinaga. 1992. Plasma vasopressin and atrial natriuretic hormone levels in hypopituitarism with and without hydrocortisone treatments: responses to an acute water load. Acta Endocrinol. 126:217-223.

Knauer, E. 1886. Einige Versuche uber Ovarien transplantation bei Kaninchen. Xentralbl. Gynaekol. 20:524-528.

Koos, R.D. and W. Hansel. 1981 The large and small cells of the bovine corpus luteum: ultrastructural and functional differences. In Dynamics of Ovarian Function, pp. 197-203. Eds N. B. Schwartz \& M. Hunzicker-Dunn. Raven Press, New York.

Kraus, W.L. and B.S. Katzenellenbogen. 1993. Regulation of progesterone receptor gene expression and growth in the rat uterus: modulation of estrogen actions by progesterone and sex steroid hormone antagonists. Endocrinology 132:23712379.

Ku, C.Y., A. Qian, Y. Wen, K. Anwer and B.M. Sanborn. 1995. Oxytocin stimulates myometrial guanosine triphosphatase and phospholipase-C activates via coupling to G alpha q/11. Endocrinology 136:1509-1515.

Lamming, G.E., D.C. Wathes, A.P.F Flint, J.H. Payne, K.R. Stevenson and J.L. Vallet. 1995. Local action of trophoblast interferons in suppression of the development of oxytocin and oestradiol receptors in ovine endometrium. J. Reprod. Fert. 105:166175.

Lau, T.M., C.B. Gow and R.J. Fairclough. 1992. Differential effects of progesterone treatment on the oxytocin-induced prostaglandin F2 alpha response and the levels of endometrial oxytocin receptors in ovariectomized ewes. Biol. Reprod.46(1):1722 .

LaVoie, H.A., A.M. Benoit, J.C. Garmey, R.A. Dailey, D.J. Wright and J.D. Veldhuis. 1997. Coordinate developmental expression of genes regulating sterol economy and cholesterol side-chain cleavage in the porcine ovary. Biol. Reprod. 57:402407.

Lipsett, M.B. 1978. Steroid hormones. In Reproductive Endocrinology, ed., Yen. S.C. and Jaffe, R.B. Philadelphia. W.B. Saunders.

Li, Y., C.J. Huang, S.J. Cho and L.L. Anderson. 1998. Differential effects of dexamethasone and RU 486, an antigestagen and antiglucocorticoid, on progesterone and relaxin secretion in hysterectomized pigs with aging corpora lutea. Anim. Reprod. Sci. 51:131-41.

Lopes, F.L., J.A. Desmarais and B.D. Murphy. 2004. Embryonic diapause and its regulation. Reproduction 128:669-678. 
Lucy, M.C., J.D. Savio, L. Badinga, R.L. De La Soto and W.W. Thatcher. 1992. Factors that affect ovarian follicular dynamics in cattle. J. Anim. Sci. 70:3615-3626.

Lutz, S.L., M.F. Smith, D.H. Keisler and H.A. Garverick. 1991.Effect of constant infusion of oxytocin on luteal lifespan and oxytocin-induced release of prostaglandin F2 alpha in heifers. Dom. Anim. Endocrinol. 8:573-85.

Magnus, V. 1901. Ovariets bteydning for svangerskabet med saerligt hensyn til corpus luteum. Nor. Mag. Laegevidensk. 62:1138-1145.

Mankey J.M. 2009. Effects of the oxytocin receptor blocker, atosiban on function of ovine corpora lutea and response to prostaglandin $F_{2}$ alpha. M.S. Thesis. West Virginia University, Davis College.

Matthews. E.L., V.J. Ayad and D.C. Wathes. 1991a. The effect of oestradiol-17B on oxytocin receptor concentration in the reproductive tract of the anestrous ewe. J. Reprod. Fertil. Abstr. Ser. 8:81.

McClellan, R.A., M.A. Dieckman, J.H. Abel and G.D. Niswender. 1975. Luteinizing hormone, progesterone and the morphological development of normal and superovulated corpora lutea in sheep. Cell and Tissue Res. 164:291-307.

McCracken, J.A., E.E. Custer and J.C. Lamsa. 1999. Luteolysis: a neuroendocrinemediated event. Physiol. Rev. 79:263-323.

McCracken, J.A., J.C. Carlson, M.E. Glew, J.R. Goding, D.T. Baird, K. Gréen and B. Samuelsson. 1972. Prostaglandin F 2 identified as a luteolytic hormone in sheep. Nat. New. Biol. 238:129-34.

McCracken, J.A., M.E. Glew, H.R. Goding, D.T Baird, K. Green and B. Samuelson. 1972. Prostaglandin F2a identified as a luteolytic hormone in sheep. Nat. New. Biol. 238:129-134.

McCracken, J.A., W. Schramm, B. Barcikowski and L. Wilson Jr. 1981. The identification of prostaglandin F2a as a uterine luteolytic hormone and the hormonal control of its synthesis. Acta Veterinaria Scandinavica Supplement. $77: 71-88$.

McNeilly, A.S., W.J. Crow and H.M. Fraser. 1992. Suppression of pulsatile luteinizing hormone secretion by gonadotrophin-releasing hormone antagonist does not affect episodic progesterone secretion or corpus luteum function in ewes. J. Reprod. Fertil. 96:865-874.

Milvae, R.A. and W. Hansel. 1980. Concurrent uterine venous and ovarian arterial prostaglandin F2a concentrations in heifers treated with oxytocin. J. Reprod. Fertil. 60:7-15. 
Mitchell, M.D., D.L. Kraemer, S.P. Brennecke and R. Webb. 1982. Pulsatile release of oxytocin during the estrous cycle, pregnancy and parturition in sheep. Biol. Reprod. 27:1169-1173.

Mead, R.A. and M.M. Joseph. 1988. Optimal dose of human chorionic gonadotropin for inducing ovulation in the ferret. Zoo Biol. 7:263-267.

Meidan, R., E. Girsh, O. Blum and E. Aberdam. 1990. In vitro differentiation of bovine theca and granulosa cells into small and large luteal-like cells: Morphological and functional characteristics. Biol. Reprod. 43:913-921.

Meyer, G.T. 1991. Ultrastructural dynamics during corpus luteum development and growth. In: Familiari, G., Makabe, S., Motta, P.M. (Eds), Ultrastructure of the Ovary. Kluwer Academic Press, Boston pp 161-176.

Moutsatsou, P. and C.E. Sekeris. 1997. Estrogen and progesterone receptors in the endometrium. Ann N Y Acad Sci. 17:99-115.

Miyamoto, A. and D. Schams. 1991.Oxytocin stimulates progesterone release from microdialyzed bovine corpus luteum in vitro. Biol. Reprod. 44:1163-1170.

Morel, A., A.M. O'Carroll, M.J. Brownstein and S.J. Lolait. 1992.Molecular cloning and expression of a rat V1a arginine vasopressin receptor.Nature 356:523-526.

Murphy, B.D. 2000. Models of luteinization. Biol Reprod. 63:2-11. Review.

Murphy, B.D. 2004. Luteinization. The Ovary. $3^{\text {rd }}$ Edition. 185-199. Academic Press., Waltham MA.

Murphy, B.D., N. Gevry, T. Ruiz-Cortes. F. Cote, B.R. Downey and J. Sirois. 2001. Formation and early development of the corpus luteum in pigs. Reproduction 58(Suppl):47-63.

Murphy, B.D. and S.L. Silavin. 1989. Luteotrophic agents and steroid substrate utilization. Oxford Rev. Reprod. Biol. 11:179-223.

Murphy-Goodwin, T., L Millar, L. North, L.S. Abrams, R.C. Weglein and M.L. Holland. 1995. The pharmacokinetics of the oxytocin antagonist atosiban in pregnant women with preterm uterine contractions. Am. J. Obstet. Gynecol. 173:913-917.

Nett, T.M., M.C. McClellan and G.D. Niswender. 1976. Effects of prostaglandins on ovine corpus luteum: blood flow, secretion of progesterone and morphology. Biol. Reprod. 15:66-78.

Niswender, G.D. 2002. Molecular control of luteal secretion of progesterone. Reproduction. 123:333-339. 
Niswender, G.D., T.L. Davis, R.J. Griffith, R.L. Bogan, K. Monser, R.C. Bott, J.E. Bruemmer and T.M. Nett. 2007. Judge, jury and executioner: the auto-regulation of luteal function. Soc. Reprod. Fertil. Suppl. 64:191-206.

Niswender, G.D. and A.R. Midgley Jr. 1970. Haptenradioimmunoassay for steroid hormones. In Immunologoic Methods in Steroid Determination (F.G. Peron and B.V. Caldwell, Eds.) pp 149-173. Appleton-Century-Crofts, New York.

Olson, P.N., T.M. Nett, R.A. Bowen, H.R. Sawyer and G.D. Niswender. 1989. Endocrine regulation of the corpus luteum of the bitch as a potential target for altering fertility. J Reprod. Fertil. Suppl. 39:27-40.

Okuda, K., A. Miyamoto, H. Sauerwein, F.J. Schweiger and D. Schams. 1992. Evidence for oxytocin receptors in cultured bovine luteal cells. Biol. Reprod. 46:1001-1007.

Ott, T.L., M.A. Mirando, M.A. Davis and F.W. Bazer. 1992. Effects of ovine conceptus secretory proteins and progesterone on oxytocin-stimulated endocmetrial production of prostagladin and turnover of inositol phosphate in ovariectomised ewes. J. Reprod. Fertil. 95:19-29.

Ottobre, J.S. 1979. Regulation of the lifespan of corpora lutea in ewes. M.S. Thesis, West Virginia University.

Padykula, H.A., L.G. Coles, W.C. Okulicz, S.I. Rapaport, J.A. McCracken, N.W. King Jr, C. Longcope and I.R. Kaiserman-Abramof. 1989. The basalis of the primate endometrium: a bifunctional germinal compartment.Biol. Reprod. 40:681-690.

Parry, D.M., D.L. Willcox and G.D. Thorburn. 1980. Ultrastructural and cytochemical study of the bovine corpus luteum. J Reprod. Fertil. 60:349-357.

Pescador, N., K. Soumano, D.M. Stocco, C.A. Price and B.D. Murphy. 1996. Steroidogenic acute regulatory protein in bovine corpora lutea. Biol. Reprod. 55:485-491.

Pescador, N., D.M. Stocco and B.D. Murphy. 1999. Growth factor modulation of steroidogenic acute regulatory protein and luteinization in the pig ovary. Biol. Reprod. 60:1453-1461.

Plotkin, D., S. Miller, S. Nakajima, E. Peskin, R. Burkman, D. Richardson, Y. Mitchel, J. Waldstreicher, M. Liu, D. Shapiro and N. Santoro. 2002. Lowering low-density lipoprotein cholesterol with simvastatin, a hydroxy-3-methylhlutaryl-coenzyme a reductase inhibitor, does not affect luteal function in premenopausal women. J. Clin. Endocrinol. Metab. 87:3155-3161.

Pierzynski P., T.M. Reinheimer and W. Kuczynski. 2007. Oxytocin antagonist may improve infertility treatment. Fertility and Sterility 88:19-23. 
Pitzel, L., I, Probst, H. Jarry and W. Wuttke. 1969. Inhibitory effects of oxytocin and vasopressin on steroid release by cultured porcine luteal cells. Endocrinology 122:1780-1785.

Prenant, A. 1898. La valeur morphologique du corps jaine; son action physiologique et therapeutique possible. Rev. Gen. Sci. Pure Appl. 9:646-650.

Priedkalns, J., A.F. Weber and R. Zemjanis. 1968. Qualitative and quantitative morphological studies of the cells of the membrame granulosa, theca interna and corpus luteum of the bovine ovary. Z. Zellforsch Mikrosk. Anat. 85:501-20.

Quirke, J.F., and J.J. Jennings, J.P. Hanrahan and J.P. Gosling. 1979. Oestrus, time of ovulation, ovulation rate and conception rate in progestagen-treated ewes given Gn-RH, Gn-TH analogues and gonadotrophins. J Reprod Fertil. 56(2):479-488.

Rajapaksha, W.R., M. McBride, L. Robertson and P.J. O'Shaughnessy. 1997. Sequence of the bovine HDL-receptor (SR-BI) cDNA and changes in receptor mRNA expression during granulosa cell luteinization in vivo and in vitro. Mol. Cell. Endocrinol. 134:59-67.

Redmer, D.A., A.T. Grazul-Bilska and L.P. Reynolds. 1991. Cell-dependent intracellular communication of bovine luteal cells in culture. Endocrinology 129:2757-2766.

Redmer, D.A. and L.P. Reynolds. 1996. Angiogenesis in the ovary. Reviews of Reproduction. 1:182-192.

Reinheimer, T.M. 2007. Barusiban suppresses oxytocin-induced preterm labour in nonhuman primates. BMC Pregnancy and Childbirth. 7(Suppl 1)1-7.

Reinheimer, T.M., W.H. Bee, J.C. Resendez, J.K. Meyer, G.J. Haluska and G.J. Chellman. 2005. Barusiban, a new highly potent and long-active oxytocin antagonist: pharmacokinetic and pharmadynamic comparison with atosiban in a cynomologus monkey model of preterm labor. J. Clin. Endocrinol. Metab. 90:2275-2281.

Renfree, M.B. and C.H. Tyndale-Biscoe. 1973.Intrauterine development after diapause in the marsupial Macropus eugenii.Dev Biol. 1:28-40.

Reynolds, L.P. and D.A. Redmer. 1999. Growth and development of the corpus luteum. J. Reprod. Fertil. Supp. 72:1857-1872.

Reversi, A., V. Rimoldi, T. Marrocco, P. Cassoni, G. Bussolati, M. Parenti and B. Chini. 2005. The oxytocin receptor antagonist atosiban inhibits cell growth via a "biased agonist" mechanism. J. Biol. Chem. 280:16311-16318. 
Rigor, E.M. and W. Hansel. 1973. In vitro progesterone synthesis by corpora lutea of hysterectomized ewes after in vivo stimulation with luteinizing hormone. J. Anim. Sci. 37:718-721.

Roberts. A.J., T.G. Dunn and W.J. Murdoch. 1985. Induction of ovulation in proestrous ewes; identification of the ovulatory follicle and functional status of the corpus luteum. Dom. Anim. Endo. 2:207-210.

Rozen, F., C. Russo, D. Banville and H.H. Zingg. 1995. Structure, characterization and expression of the rat oxytocin receptor gene. Proc. Nat. Acad. Sci. U.S.A. 92:200204.

Richards, J.S. 1980. Maturation of ovarian follicles: actions and interactions of pituitary and ovarian hormones on follicular cell differentiation. Phys. Rev. 60:51-89.

Richards, J.S., L. Hedin and L. Caston. 1986. Differentiation of rat ovarian theca cells: evidence for functional luteinization. Endocrinology. 1888:1660-1668.

Richardson, M.C. and G.M. Masson. 1985.Lack of direct inhibitory action of oxytocin on progesterone production by dispersed cells from human corpus luteum. $\mathrm{J}$ Endocrinol. 104:149-151.

Ruiz-Cortés, Z.T., S. Kimmins, L. Monaco, K.H. Burns, P. Sassone-Corsi and B.D. Murphy. 2005. Estrogen mediates phosphorylation of histone $\mathrm{H} 3$ in ovarian follicle and mammary epithelial tumor cells via the mitotic kinase, Aurora B. Mol. Endocrinol. 19:2991-3000.

Roberts, J.S., J.A. McCracken, J.E. Gavagan and M.S. Soloff. 1976. Oxytocin stimulated release of prostaglandin F2 from ovine endometrium in vitro: Correlation with estrous cycle and oxytocin-receptor binding. Endocrinology 99:1107-1114.

Rodgers, R.J., J.D. O’Shea and N.W. Bruce. 1984. Morphometric analysis of the cellular composition of the ovine corpus luteum. J. Anatomy. 138:757-769.

Rodgers, R.J. and J.D. O'Shea. 1982. Purification, morphology, and progesterone production and content of three cell types isolated from the corpus luteum of the sheep. Aust. J. Biol. Sci. 35:441-455.

Rodgers, R.J., J.D. O'Shea, J.K. Findlay, A.P. Flint and E.L. Sheldrick. 1983. Large luteal cells the source of luteal oxytocin in the sheep. Endocrinology 113:2302-2304.

Rodgers, R.J., H.F. Rodgers, M.R. Waterman and E.R. Simpson. 1986. Immunolocalization of cholesterol side-chain cleavage cytochrome P-450 and ultrastructural studies in bovine corpora lutea. Reprod. Fertil. 78:639-652. 
Rothchild, I. 1981. The regulation of the mammalian corpus luteum. Recent Prog. Horm. Res. 37:183-298.

Sangha, G.K., R.K. Sharma and S.S. Guraya. 2002. Biology of corpus luteum in small ruminants. Small Ruminant Research. 43(1):53-56.

Scaramuzzi, R.J., H.P. Boyle, A.G. Wheeler, R.B. Land and D.T. Baird. 1974. Proceedings: Preliminary studies on the secretion of prostaglandin F from the autotransplanted uterus of the ewe after exogenous progesterone and oestradiol. J. Endocrinol. 61:XXXV.

Schwall, R.H., H.R. Sawyer and G.D. Nisewender. 1986. Differential regulation by LH and prostaglandins of steroidogenesis in large and small luteal cells of the ewe. J. Reprod. Fertil. 76:821-829.

Sharma, M.K and G.R Buettner. 1993. Interaction of vitamin C and vitamin K during free radical stress in plasma. An ESR study. Free Radical Biol. Med. 14:649-653.

Sharma, R.K. and M. Sharma. 1998. Corpus luteum spurium of goat. Indian J. Anim. Sci. 68:150-152.

Sharma, S.C. and R.J. Fitzpatrick. 1974. Effect of oestradiol 17-B and oxytocin treatment on prostaglandin F alpha release in the anestrous ewe. Prostaglandins. 6:97-105.

Sharman, G.B. 1976. Evolution of viviparity in mammals. In Reproduction in Mammals. Book 6. The evolution of reproduction. 32-70. Cambridge University Press, London.

Sheldrick, E.L. and A.P.F Flint. 1985. Endocrine control of uterine oxytocin receptors in the ewe. J. Endocrinol.. 106:249-258.

Sheldrick, E.L., M.D. Mitchell and A.P. Flint. 1980. Delayed luteal regression in ewes immunized against oxytocin. J. Reprod. Fertil. 59:37-42.

Short, R.V. 1977. The discovery of the ovaries. In The Ovary (H. Zuckerman and B.J. Eds). Pp 1-39. Academic Press, New York.

Silvia, W.J., R.E. Raw, S.L. Aldrich and S.H Hayes. 1992. Uterine secretion of prostaglandin F2a in response to oxytocin in ewes: Changes during the estrous cycle and early pregnancy. Biol. Reprod. 46:1007-1015.

Singh, G.W. and P. Prakash. 1988. Histomorphological and histochemical studies on the ovary of the goat. Indian Vet. J. 65:705-709.

Simmons, K.R. and W. Hansel. 1964. Nature of luteotrophic hormones in the bovine. J. Anim. Sci. 23:136-141. 
Simpson, D.M., J.F. Elliston and J.A. Katzenellenbogen. 1987. Desmethylnafoxidine aziridine: An electrophilic affinity label for the estrogen receptor with high efficiency and selectivity. Steroid Biochem. 28:233-245.

Simpson, R.J., B. Grego, M.V. Govindan and H. Gronemeyer. 1987. Peptide sequencing of the chick oviduct progesterone receptor form B. Mol. Cell. Endocrinol. 52:177-184.

Simpson, P.J., J.C. Fantone and B.R. Lucchessi. 1987. Myocardial ischemia and reperfusion injury: oxygen radicals and the role of the neutrophil. In: Oxygen Radicals and Tissue Injury. FASEB. 63.

Silvia, W.J. and M.L. Silvia. 1989. Relationship between uterine secretion of prostaglandin $\mathrm{F} 2 \alpha$-induced by oxytocin and endogenous concentrations of estradiol and progesterone at three stages of the bovine estrous cycle. J. Anim. Sci. 67:2347-2353.

Smith. V.R., L.E. McShan and L.E. Casida. 1957. Prolactin not luteotrophic in cow. J. Dairy Sci. 40:443.

Sohl, U.S. and K. Willecke. 2004. Gap junctions and the connexin protein family. Cardiovascular Research. 62:228-232.

Soloff, M.S., M. Alexandrova and M.J. Fernstrom. 1979. Oxytocin receptors; triggers for parturition and lactation? Science. 204:1313-1215

Stocco, D.M. 2001. StAR protein and the regulation of steroid hormone biosynthesis. An. Review of Physio. 63:193-213.

Stouffer, R.L. and J.P. Hearn. 1998. Endrocrinology of the transition from menstral cyclicity to establishment of pregnancy in primates. In Endocrionology of Pregnancy. 33-57. Humana Press, Totowa, NJ.

Stouffer, R.L., F. Xu and D.M. Duffy. 2007.Molecular control of ovulation and luteinization in the primate follicle. Front Biosci. 12:297-307. Review.

Strakova. Z. and M.S. Soloff. 1997. Coupling of oxytocin receptor to G proteins in rat myometrium during labor: Gi receptor interaction. Am. J. Physiol. 272:E870-876.

Swann, R.W., P.J. O’shaughnessy, S.D. Birkett, D.C. Wathes, D.G. Porter and B.T. Pickering. 1984. Biosynthesis of oxytocin in the corpus luteum. Fed. European Biochem. Sci. 174:262-266

Thibonnier, M., C. Auzan, Z. Madhun, P. Wilkins, L. Berti-Mattera and E. Clauser. 1994. Molecular cloning, sequencing, and functional expression of a cDNA encoding the human V1a vasopressin receptor. J. Biol. Chem. 269:3304-3310. 
UK Medicines Information. 2001. New Medicines on the Market. UK Medicines Information Pharmacists Group. 1-6.

Umo, I. 1975. Effect of prostaglandin F2a on the ultrastructure and function of sheep corpora lutea. J. Reprod. Fert. 43:287-292.

Ursely, J. and P. Leymarie. 1979. Varying response to luteinizing hormone of two luteal cell types isolated from bovine corpus luteum. J. Endocrinol. 83:303-310.

Van Niekerk, C.H., J.C. Morgenthal and W.H. Gerneke. 1975. Relationship between the morphology of and progesterone production by the corpus luteum of the mare. J. Reprod. Fertil. Supp. 23:171-175.

Viero, C., I. Shibuya, N. Kitamura, A. Verkhratsky, H. Fujihara, A. Katoh, Y. Ueta, H.H. Zingg, A. Chvatal, E. Sykova and G. Dayanithi. 2010. Oxytocin: Crossing the Bridge between basic science and pharmacotherapy. CNS Neuroscience \& Therapeutics. 16:138-156.

Warbritton, V. 1934. The cytology of the corpora lutea of the ewe. J. Morph. 56:186-202.

Wathes, D.C and R.W. Swann. 1982. Is oxytocin an ovarian hormone? Nature. 20;297:225-227.

Wathes, D.C. 1984. Oxytocin and vasopressin in the gonads. In Oxford Reviews of Reproductive Physiology. S. R. Milligan, Ed. Vol. II:226-283, Oxford University Press. Oxford, New York, Tokyo.

Wathes, D.C. 1989. Oxytocin and vasopressin in the gonads. Oxford Rev. Reprod. Biol. 111:225-283.

Wathes, D.C., E.L. Matthews and V.J. Ayad. 1992. Effect of oxytocin infusion on secretion of progesterone and luteinizing hormone and the concentration of uterine oxytocin receptors during the periovulatory period in cloprostenol treated ewes. J. Reprod. Fertil. 96:657-665.

Wathes, D.C., R.W. Swann, S.D. Birkett, D.G. Porter and B.T. Pickering. 1993. Characterization of oxytocin, vasopressin and neurophysin from the bovine corpus luteum. Endocrinology. 113:693-698.

Wathes, D.C., C.L. Gilbert and V.J. Ayad. 1993. Interactions between oxytocin, the ovaries, and the reproductive tract in the regulation of fertility in the ewe. Ann. N. Y. Acad. Sci. 689:396-410.

Wellnitz, O., R.M. Bruckmaier, C. Albrecht and J.W. Blum. 1999. Atosiban, an oxytocin receptor blocking agent: pharmacokinetics and inhibition of milk ejection in dairy cows. J. Dairy. Res. 66:1-8. 
Wex J., M. Connolly and W. Rath. 2009. Atosiban versus betamimetics in the treatment of preterm labour in Germany: an economic evaluation. BMC Pregnancy and Childbirth. 9:23.

Young. L.J., Z. Wang, R. Donaldson and E.F. Rissman. 1998. Estrogen receptor alpha is essential for introduction of oxytocin receptor by estrogen. Neuroreport 9:933936.

Zeleznik, A.J. 2001. Follicle selection in primates: "many are called but few are chosen". Biol/ Reprod. 3:655-659.

Zhang, L., J.J. Dreifuss, M. Dubois-Dauphin and E. Tribollet. 1991. Autoradiographical localization of oxytocin binding sites in the guinea-pig ovary at different stages of the oestrous cycle. J. Endocrinol. 131:421-426.

Zhang, J., P.G. Weston and J.E. Hixon. 1992. Role of progesterone and oestradiol in the regulation of uterine oxytocin receptors in ewes. J. Reprod. Fertil. 94:395-404.

Zhang, M., P. Liu, N.K. Dwyer, L.K. Christenson, T. Fujimoto, F. Martinez, M.Comly, J.A. Hanover, E.J. Blanchette-Mackie and J.F. Strauss. 2002. MLN64 mediates mobilization of lysosomal cholesterol to steroidogenic mitochondria. J. Biol. Chem. 277:33300-33310. 
Effect of Intravenous Treatment with the Oxytocin Antagonist Atosiban on Circulating Progesterone in the Ewe

Todd M. Ramboldt

Thesis submitted to the

Davis College of Agriculture, Natural Resources and Design

DWJ HMO IU IQDD8 QYHUWW

in partial fulfillment of the requirements

for the degree of

Master of Science

in

Reproductive Physiology

APPROVAL OF THE EXAMINING COMMITTEE

Jorge A. Flores, Ph.D.

Robert A. Dailey, Ph.D.

Date

E. Keith Inskeep, Ph.D., Chair

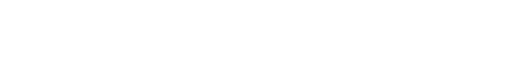

